\title{
Review \\ Nod-Like Receptors in Host Defence and Disease at the Epidermal Barrier
}

\author{
Judit Danis ${ }^{1,2,3, *}$ and Mark Mellett ${ }^{4,5}$ \\ 1 MTA-SZTE Dermatological Research Group, Eötvös Loránd Research Network, Korányi Fasor 6, \\ 6720 Szeged, Hungary \\ 2 HCEMM-USZ Skin Research Group, University of Szeged, Korányi Fasor 6, 6720 Szeged, Hungary \\ 3 Department of Medical Genetics, University of Szeged, Somogyi B u 4, 6720 Szeged, Hungary \\ 4 Department of Dermatology, University Hospital Zürich (USZ), University of Zürich (UZH), \\ Raemistrasse 100, 8091 Zürich, Switzerland; Mark.Mellett@usz.ch \\ 5 Faculty of Medicine, University of Zürich, 8091 Zürich, Switzerland \\ * Correspondence: danis.judit@med.u-szeged.hu; Tel.: +36-62-54-52-78
}

Citation: Danis, J.; Mellett, M.

Nod-Like Receptors in Host Defence and Disease at the Epidermal Barrier. Int. J. Mol. Sci. 2021, 22, 4677.

https://doi.org/10.3390/

ijms22094677

Academic Editor: Philip W. Wertz

Received: 15 March 2021

Accepted: 27 April 2021

Published: 28 April 2021

Publisher's Note: MDPI stays neutral with regard to jurisdictional claims in published maps and institutional affiliations.

Copyright: (c) 2021 by the authors. Licensee MDPI, Basel, Switzerland. This article is an open access article distributed under the terms and conditions of the Creative Commons Attribution (CC BY) license (https:/ / creativecommons.org/licenses/by/ $4.0 /)$.

\begin{abstract}
The nucleotide-binding domain and leucine-rich-repeat-containing family (NLRs) (sometimes called the NOD-like receptors, though the family contains few bona fide receptors) are a superfamily of multidomain-containing proteins that detect cellular stress and microbial infection. They constitute a critical arm of the innate immune response, though their functions are not restricted to pathogen recognition and members engage in controlling inflammasome activation, antigenpresentation, transcriptional regulation, cell death and also embryogenesis. NLRs are found from basal metazoans to plants, to zebrafish, mice and humans though functions of individual members can vary from species to species. NLRs also display highly wide-ranging tissue expression. Here, we discuss the importance of NLRs to the immune response at the epidermal barrier and summarise the known role of individual family members in the pathogenesis of skin disease.
\end{abstract}

Keywords: NLRs; skin; keratinocyte; inflammasome; skin disease

\section{Introduction}

Innate immunity relies on the recognition of evolutionarily conserved microbe-specific molecules, termed pathogen-associated molecular patterns (PAMPs). Germline encoded pattern recognition receptors (PRRs) expressed on the cell surface, endosomes or in the cytosol detect and respond to these PAMPs. Although, the domains of these PRRs are highly conserved, extensive species-specific expansions and domain shuffling result in an advantage to an organism living in pathogen-rich environments. The PRRs expressed by mammalian cells are Toll-like receptors (TLRs), the NOD-like receptors (NLRs), AIM2-like receptors (ALRs), RIG-like receptors (RLRs) and C-type lectin receptors (CLRs), with each family member recognizing specific molecular signatures [1]. Two of these families of PRRs are conserved from early invertebrates to mammals: the transmembrane TLRs and the intracellular NLRs [2,3].

Our skin acts as a sentinel organ, determining when and how to respond to a broad range of environmental insults during both homeostatic and pathologic situations. The skin forms a physical barrier through the cornified envelope of stratum corneum and via tightjunctions in lower layers, a chemical barrier by maintaining an acidic $\mathrm{pH}$ and antimicrobial peptide expression and finally, there is the immunologic barrier formed by keratinocytes and infiltrating immune cells of both the innate and adaptive immune systems [4]. These layers of barriers interact with each other to protect the organism from harmful stimuli. Keratinocytes are the main cell type of the epidermis and as immunocompetent cells are implicated in the protection against harmful threats, by the expression of a wide range of PRRs, including TLRs and NLRs [5-7]. The activation of PRRs induces keratinocytes to express antimicrobial peptides and immune mediators, which promote the recruitment 
of professional immune cells [4]. Murine and human TLRs in skin biology have been discussed elsewhere [5,6], here we will focus on the NLR family and discuss its role in the immune defence in the skin.

NLRs are cytosolic receptors widely identified in non-vertebrates and vertebrates, and have functional analogues, the R-proteins, in plants [8]. The number of NLR genes differ from species to species: humans express 23 NLR family members, while mice have at least 34 NLR paralogues (Figure 2) [1,8]. NLRs are multi-domain containing proteins, comprising of a C-terminal domain with a series of leucine rich repeats (LRRs), a central nucleotide-binding NACHT domain, and an $\mathrm{N}$-terminal effector domain [9]. The $\mathrm{N}$ terminal domain is variable, and NLRs are divided into five subfamilies based on their distinctive $N$-terminal domain: NLRAs that have an acidic activation domain, NLRBs that possess a baculovirus inhibitor of apoptosis repeat (BIR)-like domain, NLRCs that feature a caspase activation and recruitment domain (CARD) or a Death domain (DD), and the NLRP subfamily that contain a PYRIN domain [9]. The NLRX subfamily contains one member, and its nomenclature derives from an uncharacterized $N$-terminal domain that lacks homology with other NLR effector domains.

In the cytosol, NLRs remain in an auto-inhibitory state. The LRR domains are thought to be responsible for ligand binding but this has not been experimentally shown to date for most NLRs and this dearth of evidence has led to the belief that mammalian LRRs might not have necessarily retained this function $[10,11]$. The LRR region also maintains the NLR in an auto-inhibitory state, as demonstrated by the crystal structure of NLRC4, where the LRR obstructs the NACHT domain [12]. The NACHT domain possesses dNTPase activity, which governs the ATP-dependent oligomerisation. Although, the NACHT domain controls oligomerisation, additionally ligand-binding can occur in this region. Upon activation, the $N$-terminal domain activates distinctive downstream signalling cascades resulting in an inflammatory response. This innate immune response also serves to influence the adaptive arm of the immune system [1]. Despite subfamilies sharing the same domain, individual members can elicit different downstream effects. For example, the NLRC family that contains a CARD domain, induces inflammasome activation, regulates nuclear factor k-light-chain-enhancer of activated B cells (NF- $\mathrm{kB}$ ) or type I interferon (IFN) signalling pathways or engages in transcriptional regulation [13].

mRNA expression of most NLRs are found in the skin, but since NLR activation is a very complex process, and some NLRs are characterized by unique cell-type specific features, without their functional evaluation in keratinocytes, their functions cannot be clearly addressed. Cornification of keratinocytes also affects the expression of NLRs and their interacting partners (Figure 1A) [14]. Here, we will summarize the current knowledge on epidermal NLR expression and functions and their potential contribution to skin disease.

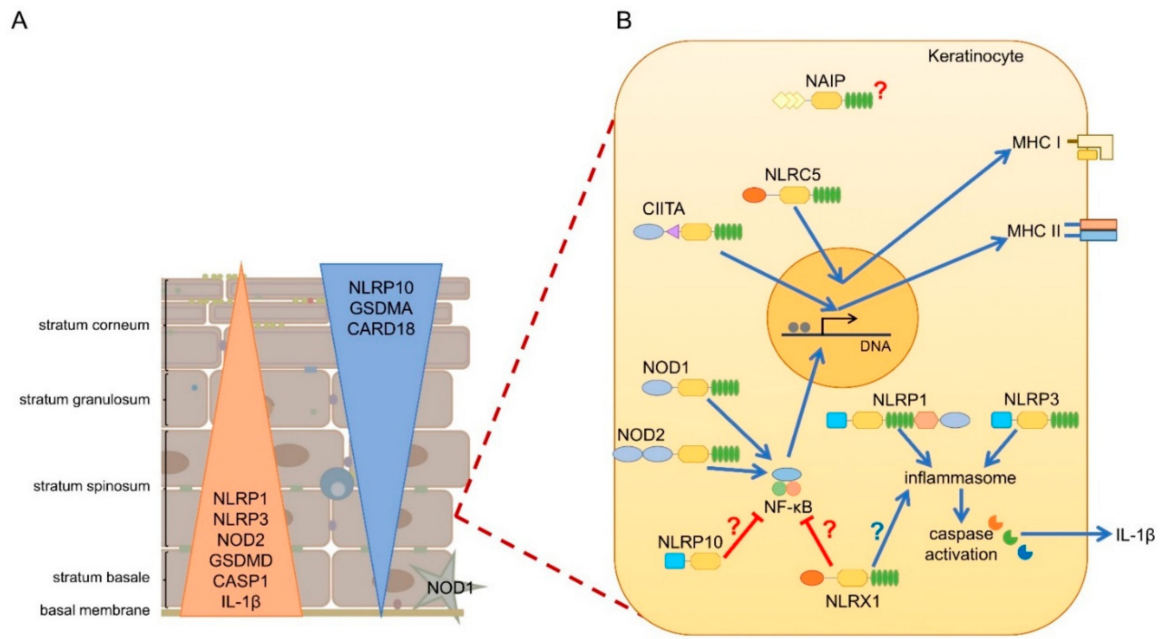

Figure 1. Expression and function of NLRs in human epidermis. (A) While inflammasome forming (NLRP1, NLRP3) and pro-inflammatory (NOD1, NOD2) NLRs are expressed in basal layers of the epidermis along with other pro-inflammatory 
genes, anti-inflammatory NLRs (NLRP10) and inflammasome inhibiting genes (CARD18) are rather enriched in the upper layers of the epidermis. (B) CIITA and NLRC5 are inducible in keratinocytes by IFN- $\gamma$ and regulates MHC II and MHC I expression, respectively. NOD1 and NOD2 is activated by bacterial products, leading to NF- $\mathrm{KB}$ activation and inflamma Table 1. and NLRP3 are both forming inflammasomes in keratinocytes leading to IL- $1 \beta$ secretion NAIP, NLRP10 and NLRX1 are expressed in keratinocytes, however their functions in keratinocytes are not described so far. NLRP10 and NLRX1 were shown to inhibit NF- $\mathrm{B}$ activity in professional immune cells and regulate inflammasome activation, however, whether these functions are dominant in keratinocytes is unknown.

\begin{tabular}{|c|c|c|c|c|c|c|}
\hline Subfamily & $\begin{array}{l}\text { Human } \\
\text { Gene }\end{array}$ & Mouse Orthologue(s) & $\begin{array}{l}\text { Protein Structure } \\
\text { (Human) }\end{array}$ & Function & Skin expression & $\begin{array}{l}\text { Associated skin } \\
\text { disease }\end{array}$ \\
\hline NLRA & CIITA & Cllta & O4C WII & MHC class II gene expression & $\begin{array}{c}\text { Inducible in } \\
\text { keratinocytes [21-24] }\end{array}$ & ND \\
\hline NLRB & NAIP & Naip1-7* & Ds-c min & $\begin{array}{l}\text { Recognition of PAMPs, inhibition of } \\
\text { apoptosis, NLRC4 Inflammasome activation }\end{array}$ & Keratinocytes [44] & ND \\
\hline \multirow[t]{5}{*}{ NLRC } & NOD1 & Nod1 & $0 \bigcirc$ Mи & $\begin{array}{l}\text { NF-KB activation, induces apoptosis and } \\
\text { autophagy, intestinal homeostasis }\end{array}$ & $\begin{array}{l}\text { Inducible in } \\
\text { keratinocytes [51], } \\
\text { immune cells [49] }\end{array}$ & $\begin{array}{l}\text { Atopic dermatitis [53, } \\
55]\end{array}$ \\
\hline & NOD2 & Nod2 & $\infty \longrightarrow$ - & $\begin{array}{l}\text { NF-KB activation, IFN \& autophagy } \\
\text { regulation, intestinal homeostasis }\end{array}$ & Keratinocytes $[50,52]$ & $\begin{array}{c}\text { Psoriasis [62, 63, 67, } \\
69], \text { atopic dermatitis } \\
{[54,55,59-61],} \\
\text { eczema, leprosy }\end{array}$ \\
\hline & NLRC3 & NIrc3 & $0 \bigcirc$ NOWN & Inhibition of T cells & - & \\
\hline & NLRC4 & Nlrc4 & orom & Inflammasome activation & - & \\
\hline & NLRC5 & Nirc5 & $0-1 \times 1$ & $\begin{array}{l}\text { MHC class I expression, innate immune } \\
\text { response regulation }\end{array}$ & $\begin{array}{l}\text { Keratinocytes, } \\
\text { fibroblasts [70] }\end{array}$ & $\begin{array}{l}\text { Pityriasis rubra pilaris } \\
{[83] \text {, melanoma [84] }}\end{array}$ \\
\hline \multirow[t]{14}{*}{ NLRP } & NLRP1 & Nlrp1a,Nlrp1b, Nlrp1c \# & $\square \bigcirc$ mй & Inflammasome activation & $\begin{array}{c}\text { Keratinocytes }[87,96, \\
108]\end{array}$ & $\begin{array}{c}\text { Sunburn, generalised } \\
\text { vitiligo [110,111], } \\
\text { atopic dermatitis [93, } \\
\text { 114], MSPC, FKLC [96], } \\
\text { psoriasis [94] }\end{array}$ \\
\hline & NLRP2 & Nlrp2 & $\square \subset \mathrm{NW}$ & $\begin{array}{l}\text { Embryogenesis, inflammasome?, negative } \\
\text { regulator of NF-KB }\end{array}$ & $\begin{array}{c}\text { Hair follicle } \\
\text { keratinocytes [117] }\end{array}$ & $\begin{array}{c}\text { Atopic dermatitis [91, } \\
117]\end{array}$ \\
\hline & NLRP3 & Nlrp3 & $\square \subset \mathrm{MW}$ & Inflammasome activation & $\begin{array}{l}\text { Keratinocytes [128, } \\
129] \text {, immune cells }\end{array}$ & $\begin{array}{l}\text { Human psoriasis [145- } \\
\text { 147], acne vulgaris } \\
\text { [138, 141], Murine } \\
\text { psoriasiform disease } \\
\text { [148], vitiligo [137] }\end{array}$ \\
\hline & NLRP4 & $\begin{array}{l}\text { Nlrp4a, Nlrp4b, Nlrp4c, Nlrp4d, } \\
\text { Nlrp4e, Nlrp4f, Nlrp4g }\end{array}$ & $\square \longrightarrow \mathrm{NM}$ & Autophagy, NF-KB, \& IFN regulation & Keratinocytes $\S[15]$ & ND \\
\hline & NLRP5 & Nlrp5 + & $\square \mathrm{MW}$ & Embryogenesis & - & ND \\
\hline & NLRP6 & Nlrp6 & $\square \bigcirc \mathrm{NW}$ & $\begin{array}{l}\text { Negative regulator of NF-kB \& IL-1 } \beta \\
\text { Canonical and non-caonical inflammasome }\end{array}$ & Keratinocytes $\S[15]$ & ND \\
\hline & NLRP7 & - & $\square \bigcirc \mathrm{NW}$ & Negative regulator of IL- $1 \beta$ & - & ND \\
\hline & NLRP8 & - & $\square \quad$ NWM & Unknown & Keratinocytes $\S[15]$ & ND \\
\hline & NLRP9 & Nlrp9a, Nlrp9b, Nlrp9c & $\square \quad$ NW & $\begin{array}{l}\text { Inflammasome activation in response to } \\
\text { Roatviurs? }\end{array}$ & - & ND \\
\hline & NLRP10 & Nlrp10 & $\square$ & Negative regulator of caspase- 1 & $\begin{array}{c}\text { Keratinocytes, } \\
\text { immune cells }[14,152, \\
153]\end{array}$ & $\begin{array}{l}\text { Atopic dermatitis [ } 55, \\
95]\end{array}$ \\
\hline & NLRP11 & - & $\square \subset$ NW & $\begin{array}{c}\text { Negative regulator of NF-KB \& IFN } \\
\text { pathways }\end{array}$ & Keratinocytes $\S[15]$ & ND \\
\hline & NLRP12 & Nlrp12 & $\square \quad$ MU & $\begin{array}{l}\text { Negative regulator of canonical and non- } \\
\text { canonical NF-kB pathways }\end{array}$ & - & Atopic dermatitis [55] \\
\hline & NLRP13 & - & $\square \bigcirc \mathrm{MW}$ & Unknown & Keratinocytes $\S[15]$ & ND \\
\hline & NLRP14 & Nlrp14 ₹ & $\square \quad$ MW & Spermatogenesis & Keratinocytes $\S[15]$ & ND \\
\hline NLRX & NLRX1 & Nlrx1 & $-\longrightarrow$ MUN & $\begin{array}{c}\text { ROS induction, regulation } \\
\text { of NF-KB \& IFN \& inflammsome }\end{array}$ & Keratinocytes [162] & ND \\
\hline
\end{tabular}

Figure 2. The NLR superfamily. Schematic depicting the five subfamilies of human NLRs and their mouse orthologues. Additionally, depicted are protein structural domains, the known function of the NLRs, their expression in skin cells and association with skin diseases. AD, Acidic transactivating domain, BIR, baculovirus IAP repeat, CARD, caspase-activation and recruitment domain, FIIND, Function-to-find domain, FKLC, familial keratosis lichenoides chronica, IFN, Interferon, LRR, Leucine-rich repeats, MSPC, multiple self-healing palmoplantar carcinoma, NACHT, a domain found in NAIP, CIITA, HET-E and TEP1, ND, not determined. * Murine Naip3 lacks a NACHT-LRR and contains three BIR domains, Naip4 lacks a NACHT-LRR and contains one BIR domain, Naip5 \& Naip6 lack an LRR region. \# Murine Nlrp1a lacks a PYRIN, Nlrp1b lacks a PYRIN and FIIND, Nlrp1c lacks PYRIN, FIIND and CARD domains. † Murine Nlrp5 lacks a PYRIN domain. $\ddagger$ Murine Nlrp14 lacks a PYRIN domain. § Based on mRNA expression assessed by Reverse Transcriptase-PCR in human primary keratinocytes [15]. 


\section{The NLRA Subfamily}

The NLRA subfamily comprises of a sole member, namely: the Class II Major Histocompatibility Complex Transactivator (CIITA), which contains an $\mathrm{N}$-terminal acidic transactivation domain, but also a CARD domain, a nuclear localization signal and four LRRs [16]. CIITA has been recognized as the "master regulator" of Major Histocompatibility Complex (MHC) class II molecule (MHC-II) expression since it controls the differential expression of MHC-II genes [17]. CIITA also plays a role in human MHC class I (MHC-I) expression, a function that is not observed in mice [18]. CIITA lacks a DNA-binding domain but controls transcription by recruiting the transcription machinery, including TFIID and TFIIB $[19,20]$. It also induces phosphorylation of RNA polymerase I and enlists the chromatin remodelling coactivators $[19,20]$.

CIITA is a founding member of the NLR protein family, but for a long time, it remained detached from the rest of the protein family as the only transcriptional regulator. Although, MHC-II is typically expressed by professional antigen-presenting cells, such as dendritic cells (DCs), B cells, macrophages, and thymic epithelial cells, it is long known that expression can also be induced in keratinocytes by IFN- $\gamma$ [21-24]. Moreover, keratinocytes express MHC-II in a variety of skin disorders, including psoriasis, allergic contact dermatitis, and atopic dermatitis, which accompanies infiltration of activated $\mathrm{T}$ cells $[25,26]$.

In mice and humans, CIITA expression is regulated by three and four distinct promoters, respectively, resulting in different isotypes $[16,22]$. Human keratinocytes mainly express type IV CIITA transcribed from promoter IV upon IFN- $\gamma$ stimulation [22], which can be further induced by interleukin (IL)-18 [27], which subsequently leads to MHC-II expression [22]. MHC-II expressing human keratinocytes have been reported to present Mycobacterium leprae antigens (hsp65) and induce the proliferation of $\mathrm{Th}_{1}$ cells, indicating that human keratinocytes can process and present some intact protein antigens [28], however, they fail to activate naïve T-cells [29-31]. In contrast, mouse keratinocytes are unable to present intact proteins to specific T cells [30]. Although keratinocytes were shown to be able to express CD86 costimulatory molecules [32], generally they do not express adequate levels of CD80/CD86 [33-35], which may explain their inability to properly activate resting or naïve $\mathrm{T}$ cells.

\section{The NLRB Subfamily}

Similarly to NLRA, the NLRB subfamily contains a single member; the neuronal apoptosis inhibitory protein (NAIP, also called NLRB1 or BIRC1) [9]. NAIP contains a BIR-like domain in its $\mathrm{N}$-terminus [9]. There is a single human NAIP orthologue but mice contain at least 7 paralogues [36]. NAIP is an anti-apoptotic protein that acts by inhibiting caspase activity by activation of mitogen-activated protein kinase (MAPK) pathways [37-39]. NAIP exerts dual-functionality as it also forms an inflammasome with NLRC4 [40]. NAIP proteins directly interact with bacterial PAMPs, including flagellin. Human NAIP also binds to the T3SS needle protein of the bacterial type III secretion systems [41]. NAIPs then recruit NLRC4 as an adaptor to induce caspase-1 activation, which it does by direct CARD:CARD interactions [42,43].

According to the Human Protein Atlas, NAIP is expressed in various cell types, including keratinocytes [44]. However, compared to other NLRs the role of NAIP in the skin is poorly studied so far. NLRC4 has not been reported to be expressed in the skin, so NAIP/NLRC4 inflammasome activation may be unlikely.

\section{The NLRC Subfamily}

The NLRC subfamily is characterized by the presence of an N-terminal CARDdomain and is the second largest subfamily of NLRs, consisting of six members: nucleotide oligomerization domain 1 (NOD1/NLRC1), NOD2 (NLRC2), NLRC3, NLRC4 and NLRC5 [45], of which NOD1, NOD2 and NLRC5 are expressed in the skin and keratinocytes, to varying extents [46]. 


\subsection{NOD1 and NOD2}

NOD1 and NOD2 are prototypic PRRs and recognize intracellular bacterial peptidoglycans motifs, having one (NOD1) or two (NOD2) N-terminal oligomerization CARD domains [47]. Both receptors bind to the membrane of early endosomes and oligomerise upon ligand binding, leading to the activation of downstream signalling of NF- $\mathrm{kB}$ and MAPK pathways [45], or the activation of autophagy independently of NF- $\mathrm{KB}$ [48].

Both NOD1 and NOD2 are expressed in the skin, although NOD1 is mainly expressed by skin-homing immune cells [49], while NOD2 expression is comparable in both immune cells and basal keratinocytes (Figure 1A) [50]. In human keratinocytes, NOD1 expression is induced by IFN- $\gamma$ and was shown to activate IL-8 expression in response to Pseudomonas aeruginosa [51]. NOD2 mediates beta-defensin-2 expression in keratinocytes subsequent to muramyl dipeptide exposure [52].

Skin Diseases Associated with NOD1 and NOD2 Functions

Genetic variants for both NOD1 and NOD2 (and also NLRP12) are linked to atopic dermatitis [53-55]. Atopic dermatitis is the most common inflammatory skin disease [56] and is characterized by impaired skin barrier function, reduced expression of antimicrobial peptides and $\mathrm{Th}_{2}$-driven inflammation. Atopic dermatitis is also accompanied by a defect in innate immune receptor functions and colonization by Staphylococcus aureus (S. aureus) $[4,57]$. It is thought, that the "leaky" epithelial barrier promotes allergen sensitization and susceptibility to microbial colonization [58]. In atopic dermatitis cohorts NOD1 SNPs were associated with increased IgE levels, and more weakly with atopic dermatitis [53], while a polymorphic NOD2 allele was associated with an almost 2-fold risk of atopic dermatitis [54]. Furthermore, a missense variant of NOD2 and a rare NOD1 haplotype were observed more frequently in patients with atopic dermatitis than in control subjects [55]. Functional deficiencies in NOD2 might result in a higher risk of S. aureus colonization, often observed in atopic dermatitis. Nod2-deficient mice display impaired clearance of $S$. aureus after subcutaneous or intraperitoneal infection $[59,60]$. Human data show $S$. aureus-induced activation of NOD2 in keratinocytes results in increased expression of IL-17C, a pathway that might be dysregulated in atopic dermatitis [61].

Although, two missense mutations of NOD2 (R702W, G908R) and one frame-shift mutation Leu1007fsinsC (3020insC) were suggested to be genetic risk factors for psoriasis [62], there is no clear association of NOD2 genetic variants to the disease [63]. Psoriasis pathogenesis arises from a complex interplay of the innate immune response in keratinocytes, skin-resident immune cells and infiltrating leukocytes [64]. Though, neutrophils and myeloid cells play an important role, immunopathogenesis is also driven by $\mathrm{Th}_{1}$ and $\mathrm{Th}_{17}$ cells. The development of psoriatic plaques is caused by the interaction of keratinocytes with these infiltrating immune cells, leading to uncontrolled keratinocyte proliferation and dysfunctional differentiation. However, keratinocytes can have an initiating role in disease development $[65,66]$. NOD2 is also highly expressed in psoriatic skin [67] and Nod2 ${ }^{-/-}$mice are more susceptible to imiquimod-induced psoriasiform disease, suggesting an inflammation-limiting role of Nod2 in murine disease. Moreover, chronic activation of NOD2 by muramyl dipeptide induces tolerance to bacterial products [68], and topical treatment with muramyl dipeptide is an effective therapy for psoriasis treatment [69].

\subsection{NLRC5}

NLRC5 is abundant in human skin with similar expression levels in keratinocytes to other cell types [70]. NLRC5 has the highest homology to CIITA and also contains a nuclear localization sequence. The inclusion of NLRC5 in the NLRC family is due to the presence of a CARD-like domain [71]. NLRC5 shuttles between the cytoplasm and nucleus and similar to CIITA induces the transcription of MHC class I genes in mouse and human cells [72-74]. Like CIITA, NLRC5 also forms an enhanceosome and domain swapping experiments showed that the DD domain of both act as transcriptional activation domains [75]. 
Besides its role in regulating antigen presentation, NLRC 5 also plays a role in several cellular inflammatory reactions [76]. In certain cell types, NLRC5 serves as a negative regulator of NF-KB activity by blocking the phosphorylation of IKK $\alpha$ and IKK $\beta[77,78]$. It was also reported to both promote and limit the antiviral type I interferon responses $[77,79-81]$. NLRC5 was also demonstrated to cooperate with the NLRP3 inflammasome in response to bacterial infection [82]. However, whether NLRC5 exerts any of these functions in the epidermis or in keratinocytes has not been studied so far.

\section{Skin Diseases Associated with NLRC5 Functions}

Although NLRC5 functions have not been deeply studied in keratinocytes, its role in skin immune responses is supported by a genetic study. In a family, harbouring a pityriasis rubra pilaris (PRP)-causing gain-of-function CARD14 mutation, the clinical manifestation was milder in a family member, who also carried an additional mutation of NLRC5. This suggests a potential interplay of the two molecules in mediating the inflammatory response in keratinocytes [83]. Interestingly, the epigenetic modifier Protein arginine methyltransferase 5 (PRMT5) downregulates NLRC5 expression in melanoma cells, leading to a decrease of MHC-I-mediated antigen presentation. Knockdown of PRMT5 promoted MHC-I accumulation at the cell surface of melanoma cells [84]. NLRC5 is also highly expressed in keloids, fibrotic tumours in the skin that arise due to fibroblast hyperproliferation and increased expression of the extracellular matrix. Knockdown of NLRC5 inhibits production of extracellular matrix components in keloid fibroblasts [85].

\section{The NLRP Subfamily}

The NLRP subfamily has 14 members in humans, of which NLRP7, NLRP8, NLRP11 and NLRP13 have no orthologues in mice, while other members of the family have three (NLRP1, NLRP9), or seven (NLRP4) murine orthologues (Figure 2) [86]. NLRP proteins are characterized by the presence of an $\mathrm{N}$-terminal PYRIN domain, allowing the recruitment of the inflammasome-activating scaffold protein Apoptosis-associated speck-like protein containing a CARD (ASC) [1]. Gene-expression of most NLRPs can be detected in immune cells and in keratinocytes [15]. Besides protein expression in immune cells, NLRP1 [87], NLRP3 [88] and NLRP10 [14] are found in human skin samples, with other members being more predominantly expressed in other tissues.

Some members of the NLRP family (NLRP1, NLRP3, NLRP6, NLRP7 and NLRP12) form inflammasomes, leading to the activation of inflammatory caspases with subsequent IL-1 $\beta$ processing and release via inflammatory cell death, termed pyroptosis [89]. Unlike professional immune cells, human keratinocytes do not need a priming signal to express inflammasome components, such as NLRP1, NLRP3, pro-IL-1 $\beta$, ASC or pro-caspase$1[15,87,90]$. Moreover, the involvement of the NLRP subfamily to various skin diseases has been shown by association of genetic variants to inflammatory skin lesions, such as psoriasis, atopic dermatitis, and vitiligo as well as skin cancers [91-96].

\subsection{NLRP1}

NLRP1 was the first described member of the NLRP subfamily to form inflammasome [97]. There are three murine NLRP1 homologues to the gene: Nlrp1a, Nlrp1b, Nlrp1c [1,98]. NLRP1 contains an N-terminal PYRIN domain, a NACHT domain, LRRs, but also harbours a C-terminal function-to-find domain (FIND) and a CARD domain, through which it can directly activate caspase-1, albeit association with ASC enhances this activation [99]. Interestingly, murine NLRP1 orthologues, Nlrp1a, -b and -c lack PYRIN domains [100]. Activation of NLRP1 is unique among the NLRP family, as it undergoes auto-proteolysis within the FIIND and the resulting $N$ - and $C$-terminal fragments remain non-covalently associated and auto-inhibited [101]. Murine Nlrp1b was shown to be subsequently subjected to "functional degradation", where the inhibitory $N$-terminal domain is targeted for $\mathrm{N}$-end rule ubiquitination and proteasomal degradation, thus liberating and activating the $C$-terminal fragment, which can form an inflammasome with capase- 
1 [102]. Human NLRP1 was initially described to be activated by muramyl dipeptide, while the murine protein is activated by Bacillus anthracis lethal toxin [103-105] and Toxoplasma gondii [106]. More recently, NLRP1 was found to be activated in response to viral agonists, including dsRNA in keratinocytes, which binds directly to the NACHT-LRR region and induces ATP hydrolysis by the NACHT domain [107]. Ultraviolet B irradiation (UVB) also induces activation of the NLRP1 inflammasome in human skin and keratinocytes, while murine keratinocytes fail to activate inflammasome upon UVB exposure $[87,90]$. However, UVB irradiation does induce IL- $1 \beta$ release in murine skin, which is mediated by infiltrating professional immune cells (mainly dendritic cells) and not keratinocytes [87]. These result show the poor conservation of the NLRP1 pathway between human and mouse skin [108]. Interestingly, 3C proteases and dsRNA only activate human NLRP1, whereas Anthrax Lethal Factor metalloprotease induces cleavage of murine Nlrp1b but not the human form [109]. T. gondii infection and Dpp8/9 inhibition with Talabostat (Val-boroPro) commonly activated both murine and human isoforms. Interestingly, Talabostat activates CARD8 in THP-1 cell-lines but triggers NLRP1 activation in keratinocytes, despite both cell types expressing both sensors [108].

\section{Skin Diseases Associated with Genetic Variants in NLRP1}

The human NLRP1 gene is highly polymorphic and GWAS studies have linked NLRP1 SNPs to congenital toxoplasmosis, Addison's disease (hypocortisolism and adrenal insufficiency) but also to generalized vitiligo [110,111]. Vitiligo is an autoimmune depigmenting disorder where infiltrating and skin-resident CD8+ cytotoxic T cells induce the loss of melanocytes [112].

Additionally, germline mutations that disrupt the PYRIN and LRR domains are reported to cause two skin disorders: multiple self-healing palmoplantar carcinoma (MSPC) and familial keratosis lichenoides chronica (FKLC) [96]. Interestingly, these diseases are not associated with fever, which typically accompanies inflammasome-related syndromes. PYRIN and LRR domains promote auto-inhibition of NLRP1 and mutations disturb this regulatory mechanism, lowering the threshold of NLRP1 activation. This leads to skin hyperplasia and formation of keratoacanthoma, the continuous cycles of immune clearance and inflammasome activation may promote the acquisition of oncogenic mutations that facilitate the development of squamous cell carcinoma. This is an interesting association of NLRP1 and skin cancer, reinforced by the fact that the NLRP1 agonist, UVB irradiation, is a primary risk factor for keratinocyte carcinomas [96,108,113].

Polymorphisms in NLRP1 that could alter protein expression, can lead to a dysregulation in pathogen recognition and response in atopic dermatitis patients. In severe cases NLRP1 expression shows an inverse correlation with symptoms. The impaired wound healing and defense responses in atopic dermatitis might be caused by the downregulation of NLRP1 expression [114]. The missense variants, potentially affecting NLRP1 functions were predicted to be functionally significant in the susceptibility of atopic dermatitis [93].

\subsection{NLRP2}

NLRP2 has a role in embryo development but its role in inflammasome activation is less clear. NLRP2 inhibits NF- $\mathrm{KB}$ activation but activates caspase-1 transcription [115]. NLRP2 was reported to form inflammasomes in gingival epithelial cells but whether it is expressed or functional in epithelial skin is not elucidated [116].

\section{Skin Diseases Associated with NLRP2 Functions}

Although, NLRP2 is not highly expressed in human or mouse skin, association of decreased NLRP2 expression with early onset atopic dermatitis was described due to promoter hypermethylation in immune cells of the patients [91]. Additionally, NLRP2 and IL-1 $\beta$ expression was more upregulated in human hair follicle-derived keratinocytes from atopic dermatitis patients than controls [117] and it would be of interest to further explore whether the NLRP2 inflammasome plays a role in atopic dermatitis-associated inflammation. 


\subsection{NLRP3}

NLRP3 is the mostly extensively studied member of the NLRP subfamily and is predominantly expressed in immune cells. NLRP3 activation in immune cells requires a two-step process with a priming signal for transcriptional induction of signalling molecules, including NLRP3 itself, followed by a second, inflammasome activating signal. Both human and murine NLRP3 inflammasome activation can be initiated by numerous signals derived from cellular damage, such as ATP release [118], potassium efflux [119], reactive oxygen species, cathepsins and microcrystals [120], but activation by microbial products has also been described [121,122]. However, due to the diversity of these agonists, it is likely that NLRP3 does not bind directly to microbial PAMPs but instead detects cellular perturbation as part of a "Guard model", similar to the detection of Rho GTPases by Pyrin after bacterial infection [13].

Upon activation, NLRP3 undergoes a conformational change permitting NACHT domain-mediated oligomerisation. This aids recruitment of ASC to the PYRIN domain of NLRP3, and ASC further forms polymers that engages pro-caspase-1. Caspase- 1 undergoes auto-cleavage and cleaves pro-IL-1 $\beta$ to its mature form [123]. In addition, to this "canonical" inflammasome, NLRP3 can also engage in a second "non-canonical" inflammasome. In response to intracellular lipopolysaccharide, caspase-11 (in mouse, caspase-4 and -5 in humans) undergoes oligomerization and auto-activation. Caspase- 11 cleaves Gasdermin D (GSDMD), which forms pores permitting the escape of mature IL-1 $\beta$ and IL-18 [124]. However, these pores upset the osmotic balance between the intra- and extracellular environments triggering pyroptosis. $\mathrm{K}^{+}$efflux as a result of these pores activates NLRP3 downstream of caspase-11 [125]. Caspase-1 also cleaves GSDMD, an event essential in pyroptosis, downstream of the canonical inflammasome [126]. In macrophages, GSDMD cleavage by caspase- 1 results in pyroptosis, but in human primary keratinocytes GSDMD is a poor substrate of caspase- 1 and rather supports secretion of IL- $1 \beta$, without pyroptosis [127].

Although, NLRP1 is regarded as the principal inflammasome sensor in human keratinocytes $[87,96,108]$ expression of NLRP3 can also be detected in basal keratinocytes (Figure 1A) [128,129]. NLRP3 activation in human keratinocytes can be initiated by various signals $[128,129]$ but without a need for a priming signal. Human keratinocytes respond to viral RNA with caspase- 1 activation and subsequent IL-1 $\beta$ and IL-18 release, which is dependent on NLRP3 [129]. Zhang and colleagues reported that soluble CD100 binds to PlxnB2 and activates NLRP3 in keratinocytes, leading to IL-1 $\beta$ and IL-18 release [130]. UVB irradiation also indirectly causes NLRP3 inflammasome activation in keratinocytes by inducing cyclobutane pyrimidine dimer formation in the DNA, and the damaged DNA can induce NLRP3 inflammasome activation, leading to IL-1 $\beta$ release [131]. Inflammasome activation is also indispensable for the normal wound healing processes, as demonstrated in mouse models, mainly due to macrophages and fibroblasts, not due to keratinocytes [132,133]. However, overactivation of inflammasomes has an opposing effect, and inhibits normal wound healing [134,135].

\subsubsection{The Role of NLRP3 in Skin Diseases}

NLRP3 has been described to have indispensable role in the pathogenesis of numerous skin diseases, including acne, atopic dermatitis, urticaria (or hives), bullous pemphigoid, vitiligo and psoriasis [136,137].

NLRP3 is activated in sebocytes by Cutibacterium acnes (previously referred to as Propinibacterium acnes) [138], the prominent member of microbiota, which is thought to be responsible for acne vulgaris formation $[139,140]$. Moreover, genetic variants of NLRP3 could also be linked to acne vulgaris in a Han Chinese population [141].

Although genetic predispositions of NLRP3 have not been discovered for atopic dermatitis [57], experimental data suggests that activation of the NLRP3 inflammasome might play a role in the disease. Expression of NLRP3 and caspase-1 was significantly impaired in lesional skin of atopic dermatitis patients compared to healthy controls [88]. 
Allergens and atopic dermatitis triggers, such as S. aureus-derived compounds can also activate NLRP3 in monocytic cells [142,143], in human keratinocytes [144], and in mouse keratinocytes [15].

In human and murine psoriatic skin NLRP3 expression is upregulated [145,146]. Two NLRP3 SNPs (rs3806265 and rs10754557) were found to be significantly related to psoriasis in a Han Chinese population [147]. In this same study, NLRP1 SNPs were found to have no significant relation to psoriasis, though in another study in a Swedish cohort, NLRP1 SNPs were linked to psoriasis susceptibility [94]. Interestingly, ASC shows elevated expression in psoriatic epidermis and also displays more nuclear expression compared to control skin [67]. NLRP3 inflammasome inhibitor, CP-456,773 (now renamed MCC950) significantly alleviated murine imiquimod-induced psoriasiform disease [148]. Similarly, cycloastragenol that also inhibits NLRP3-mediated pyroptosis can also decrease symptoms in imiquimod-induced skin inflammation in mice [149]. These findings suggest that targeting NLRP3 could be avenue to explore for psoriasis treatment.

\subsubsection{Inflammasome Activation and Epidermal Differentiation Are Interconnected}

Proteins of the gasdermin (GSDM) family are not only involved in inflammasome activation and pyroptosis, but are also indispensable for normal terminal differentiation and cornification processes in the skin $[14,150,151]$. The most prominent member of the family is GSDMD. All GSDMs are activated by proteolytic cleavage by caspases between the $\mathrm{N}$-terminal pore-forming and a $\mathrm{C}$-terminal repressor domain, allowing for pore formation. GSDMs involved in inflammatory processes (i.e., GSDMD and GSDME) are expressed in basal layers of skin. However, during terminal differentiation their expression decreases in human keratinocytes along with the inflammasome components and substrate IL-1 $\beta$ (Figure 1A) [14]. These results suggest that human epidermal cornification is accompanied by a tight control of inflammasome activation and it is of interest to further tease out the role of this protein family in these divergent types of cell death in the skin.

\subsection{NLRP10}

Both human and murine NLRP10 are highly expressed in the epidermis and contribute to cell-autonomous responses against invasive bacteria [152]. Compared to other organs, murine epidermis was found to show the highest expression of Nlrp10 mRNA [153]. Since NLRP10 lacks the prototypical C-terminal leucine-rich repeats, it is thought to function as a signalling modifier. Indeed, NLRP10 positively regulates innate immune responses mediated by NOD1 upon Shigella flexneri infection in both epithelial cells and dermal fibroblasts by modulating p38 MAPK and NF-KB signalling [152]. Human NLRP10 inhibits ASCmediated NF- $\mathrm{KB}$ activation and caspase- 1 maturation of IL-1 $\beta$ [154]. However, immune cells from Nlrp10 knock-out mice respond normally to inflammasome activation [155,156], suggesting a difference in function between the human and mouse proteins.

In mice, Nlrp10 has a bridging function between the innate and adaptive immune responses through DC activity. Against T-cell dependent antigens Nlrp10-deficient mice show no efficient antigen specific immune responses due to impaired DC responses [156], which also impairs the response to infection of the fungal pathogen Candida albicans [155]. The lack of connection between the adaptive and innate immune system in the absence of Nlrp10 was further shown in other models. Nlrp10 knock-out mice had significantly decreased inflammation in induced-contact hypersensitivity models and this was accompanied by a decreased infiltration of T cells. Mice with epidermal-specific knockout of Nlrp10 expression also displayed less inflammation but no loss of infiltrating $T$ cell numbers [157]. Interestingly, NLRP10 expression among other inflammasome regulators was strongly induced in differentiated human keratinocytes (Figure 1A) [14]. Moreover, GWAS studies also linked NLRP10 genetic variants to atopic dermatitis [55,95], a skin disease accompanied by abnormal differentiation and decreased barrier functions [158]. These data strongly suggest a physiological role of NLRP10 in the skin, in addition to immune cells. 


\section{The NLRX Subfamily}

The sole member of the NLRX family, NLRX1 contains a dissimilar and uncharacterised $N$-terminal effector domain compared to other NLRs. It also has an unusual C-terminus, which contains seven LRRs and a three-helix bundle [159]. Within the $\mathrm{N}$ terminus NLRX1 contains a mitochondria-targeting sequence [160-162] and is involved in mitochondrial reactive oxygen species (ROS) formation [162]. Additionally, NLRX1 attenuates NF- $\mathrm{KB}$ and inflammasome signalling $[162,163]$. The regulatory effects of NLRX1 are highly cell type specific, which might be determined by the unique functional activity or metabolic profile of the given cell type [164]. NLRX1 is ubiquiteously expressed, including in keratinocytes, but its function in the skin is currently unknown.

\section{NLRs in Human and Mouse Skin}

Animal models are indispensable to study the mechanism of human diseases. The mouse represents one of our most reliable animal models, supported by results of human and murine genome sequencing, which reveal that only a couple hundreds of genes appear to be unique to one species or the other [165]. However, in the study of immune-derived skin diseases, it is challenging to translate results derived from mouse to human. There are several structural and functional differences between mouse and human skin. Human skin is thicker, with 5 to 10 cell layers in the epidermis, adhering tightly to underlying tissues, while murine skin is thinner and loose, containing only 2 to 3 cell layers in the epidermis, associated with decreased barrier function and increased absorption of murine skin [166].

In general, it is believed that murine and human keratinocytes share many common characteristics. Both mouse and human epidermis are implicated in the protection against endogenous and exogenous harmful stimuli, however, their immunological mechanics differ. While human keratinocytes express a wide range of PRRs, actively participating in immune defence against skin-invading pathogens, in murine skin a higher number of skin-resident professional immune cells perform these defence functions [87].

While there are numerous comparative analyses on TLR expression and functions in skin cells of various species, including human and murine keratinocytes [3,5,165,167-170], there is limited information on NLR function in these cell types. Both human and mouse keratinocytes were shown to express NLR proteins (Figure 2) however their activators are highly cell-type specific, thus their functions might differ from professional immune cells. The few studies comparing NLR expression and function in human and mouse keratinocytes or skin have shown differences in their functions with significantly lower expression in murine keratinocytes than in human cells (Table 1).

CIITA is expressed in both human and mouse keratinocytes regulating MHC-II expression. However, while human keratinocytes are able to use the expressed MHC molecules for antigen presentation to T-cells, murine keratinocyte are unable to do so [29-31]. NLRP1 is expressed and functional in human keratinocytes, its mouse orthologues are not expressed in keratinocytes rather in skin-homing immune cells [87]. Interestingly, intact skin of both human and mouse produce the same mediators upon the NLRP1 activating UVB exposure, but while in humans the process is mediated by NLRP1 in keratinocytes, in mouse skin the immune cells are responsible for this phenomenon [87]. Similarly, NLRP3 is also expressed and functional in human keratinocytes [128,129], but not in murine epidermis [171]. In human cells, NLRP10 regulates inflammasome activation [152,154], while Nlrp10 knock-out mice respond normally to inflammasome activation [155,156], suggesting a difference in function between the human and mouse proteins.

Not only are NLRs differentially expressed in skin samples, but other components of inflammasome activation also show differences between species. Especially during terminal differentiation expression of inflammasome inhibitors, including CARD18, increases $[14,172,173]$, while expression of inflammasome members, pore-forming GSDMs and inflammasome substrate IL-1 $\beta$ decreases (Figure 1A) [14].

Expression of GSDMA also increases in differentiated keratinocytes, suggesting a function for GSDMA during cornification (Figure 1A) [14,150]. While humans have one 
GSDMA gene, mice have three orthologues, Gsdma, Gsdma2, Gsdma3. Knock-out mouse models showed the involvement of Gsdma3 and Gsdma in terminal differentiation of keratinocytes and hair follicle formation, respectively. Mutations in Gsdma3 were also linked to alopecia in mice, however these results have so far not been corroborated in human studies [151].

This would indicate that results obtained in mouse models require careful interpretation, and comparison with human data, to draw precise conclusions on NLR functions. Thus far, most of our knowledge on the functions NLRs in skin biology have come from mouse models. However, mice and humans have striking differences in their skin structure and NLR expression and functions between human and murine keratinocytes.

Table 1. Comparison of human and murine NLR functions.

\begin{tabular}{|c|c|c|c|}
\hline Human Gene & Murine Gene & Function in Human Keratincoytes/Skin & Function in Murine Keratinocytes/Skin \\
\hline CIITA & CIIta & $\begin{array}{c}\text { Inducible in keratinocytes }[21,22,24] \\
\text { Regulates MHC-II expression and } \\
\text { presentation of intact proteins to T-cells } \\
{[22,27,28]}\end{array}$ & Inducible in keratinocytes $[23,30]$ \\
\hline NOD2 & Nod2 & $\begin{array}{c}\text { Gene variants associated with atopic } \\
\text { dermatitis [53-55] } \\
\text { Deficiency promotes Staphylococcus aureus } \\
\text { colonisation [61]. } \\
\text { Upregulated in psoriasis [67] }\end{array}$ & $\begin{array}{c}\text { Nod2 }{ }^{-/-} \text {are unable to clear Staphylococcus } \\
\text { aureus infection } \\
{[59,60]} \\
\mathrm{Nod}^{-/-} \text {mice are susceptible to } \\
\text { imiquimod-induced psoriasiform } \\
\text { disease [68] }\end{array}$ \\
\hline NLRP1 & $\begin{array}{l}\text { Nlrp1a, Nlrp1b, } \\
\text { Nlrp1c \# }\end{array}$ & $\begin{array}{c}\text { Expressed in keratinocytes [87] } \\
\text { dsRNA and UVB induced activation in } \\
\text { keratinocytes }[87,90,107]\end{array}$ & $\begin{array}{l}\text { Not expressed in keratinocytes [87] } \\
\text { UVB induced activation in skin-homing } \\
\text { immune cells [87] }\end{array}$ \\
\hline NLRP3 & Nlrp3 & $\begin{array}{c}\text { Expressed and activated in } \\
\text { keratinocytes [128,129] } \\
\text { Activated in sebocytes by Cutibacterium } \\
\text { acnes [138] } \\
\text { Activated in keratinocytes by Staphylococcus } \\
\text { aureus [144] } \\
\text { Upregulated in psoriasis [145] }\end{array}$ & $\begin{array}{c}\text { Expressed mainly in skin-homing immune } \\
\text { cells }[132,133] \\
\text { Role in wound healing }[132,133] \\
\text { Activated in keratinocytes by Staphylococcus } \\
\text { aureus }[15] \\
\text { Upregulated in psoriasiform disease } \\
{[146,148,149]}\end{array}$ \\
\hline NLRP10 & Nlrp10 & $\begin{array}{c}\text { Expressed in differentiated } \\
\text { keratinocytes }[14,152] \\
\text { Gene variants associated with atopic } \\
\text { dermatitis }[55,95] \\
\text { Regulates inflammasome activation }[152,154]\end{array}$ & $\begin{array}{c}\text { Expressed in differentiated } \\
\text { keratinocytes }[14,153] \\
\text { Plays a role in contact hypersensitivity [157] } \\
\text { Nlrp } 10^{-/-} \text {mice exhibit normal } \\
\text { inflammasome activation }[155,156]\end{array}$ \\
\hline
\end{tabular}

\section{Conclusions}

Since the discovery of NLRs, our knowledge has rapidly increased on their functions and regulation, especially in professional immune cells. Several NLRs are expressed in skin, while evidence is lacking for the expression of others. Skin is the first line of defence against invading pathogens. Keratinocytes are the main cell type of the epidermis and as immunocompetent cells are implicated in the protection against harmful stimuli, partially due through NLR activation. Moreover, terminal differentiation of keratinocytes also affects the expression of NLRs and their interacting partners. This dichotomy of expression of individual NLRs in proliferating and differentiating keratinocytes is intriguing and warrants further investigation. It should be noted that mRNA levels of most NLRs are found in skin and since some inflammasome components require a "priming" step, it cannot be ruled out that in particular inflammatory contexts expression of certain NLRs are not enhanced. NLR activation is a very complex process, moreover, some NLRs are characterized by unique features which can be also dependent on the cell-type. Therefore, without functional evaluation of NLRs in keratinocytes, their functions cannot be clearly 
addressed. However, as the field grows, a better understanding on specific NLR functions in the skin and an appreciation of their contribution to skin disease can be expected in the near future.

Funding: J.D. is supported by the Hungarian National Research, Development and Innovation Office Grant no. FK 134355, by the Bolyai János Research Fellowship and the Bolyai + Fellowship (UNKP-20-5, New National Excellence Program of the Ministry for Innovation and Technology from the source of the National Research Development and Innovation Fund). M.M. would like to thank the SNSF Scientific Exchanges program (185113).

Institutional Review Board Statement: Not applicable.

Informed Consent Statement: Not applicable.

Data Availability Statement: Not applicable.

Conflicts of Interest: The authors declare that the literature research and writing of the manuscript were performed in the absence of any commercial or financial relationships that could be construed as a conflict of interest.

\section{References}

1. Chandler, C.E.; Harberts, E.M.; Ernst, R.K. Pathogen Sensing: Toll-Like Receptors and NODs (Innate Immunity). In Encyclopedia of Microbiology (Fourth Edition); Elsevier: Amsterdam, The Netherlands, 2019; pp. 443-456.

2. Zhang, Q.; Zmasek, C.M.; Godzik, A. Domain architecture evolution of pattern-recognition receptors. Immunogenetics 2010, 62, 263-272. [CrossRef]

3. Jann, O.C.; King, A.; Lopez Corrales, N.; Anderson, S.I.; Jensen, K.; Ait-ali, T.; Tang, H.; Wu, C.; Cockett, N.E.; Archibald, A.L.; et al. Comparative genomics of Toll-like receptor signalling in five species. BMC Genom. 2009, 10, 1-15. [CrossRef] [PubMed]

4. Kuo, I.-H.; Yoshida, T.; De Benedetto, A.; Beck, L.A. The cutaneous innate immune response in patients with atopic dermatitis. J. Allergy Clin. Immunol. 2013, 131, 266-278. [CrossRef]

5. Sun, L.; Liu, W.; Zhang, L.J. The Role of Toll-Like Receptors in Skin Host Defense, Psoriasis, and Atopic Dermatitis. J. Immunol. Res. 2019, 1824624. [CrossRef]

6. Miller, L.S. Toll-like receptors in skin. Adv. Dermatol. 2008, 24, 71-87. [CrossRef] [PubMed]

7. Tang, L.; Zhou, F. Inflammasomes in Common Immune-Related Skin Diseases. Front. Immunol. 2020, 11, 1-15. [CrossRef]

8. Shaw, M.H.; Reimer, T.; Kim, Y.-G.; Nuñez, G. NOD-like receptors (NLRs): Bona fide intracellular microbial sensors. Curr. Opin. Immunol. 2008, 20, 377-382. [CrossRef] [PubMed]

9. Ting, J.P.Y.; Lovering, R.C.; Alnemri, E.S.P.D.; Bertin, J.; Boss, J.M.; Davis, B.; Flavell, R.A.; Girardin, S.E.; Godzik, A.; Harton, J.A.; et al. The NLR gene family: An official nomenclature. Immunity 2008, 28, 285-287. [CrossRef] [PubMed]

10. Bentham, A.; Burdett, H.; Anderson, P.A.; Williams, S.J.; Kobe, B. Animal NLRs provide structural insights into plant NLR function. Ann. Bot. 2016, 119, 698-702. [CrossRef] [PubMed]

11. Tenthorey, J.L.; Kofoed, E.M.; Daugherty, M.D.; Malik, H.S.; Vance, R.E. Molecular Basis for Specific Recognition of Bacterial Ligands by NAIP/NLRC4 Inflammasomes. Mol. Cell 2014, 54, 17-29. [CrossRef]

12. Hu, Z.; Yan, C.; Liu, P.; Huang, Z.; Ma, R.; Zhang, C.; Wang, R.; Zhang, Y.; Martinon, F.; Miao, D.; et al. Crystal Structure of NLRC4 Reveals Its Autoinhibition Mechanism. Science 2013, 341, 172-175. [CrossRef] [PubMed]

13. Meunier, E.; Broz, P. Evolutionary Convergence and Divergence in NLR Function and Structure. Trends Immunol. 2017, 38 , 744-757. [CrossRef] [PubMed]

14. Lachner, J.; Mlitz, V.; Tschachler, E.; Eckhart, L. Epidermal cornification is preceded by the expression of a keratinocyte-specific set of pyroptosis-related genes. Sci. Rep. 2017, 7, 17446. [CrossRef] [PubMed]

15. Watanabe, H.; Gaide, O.; Pétrilli, V.; Martinon, F.; Contassot, E.; Roques, S.; Kummer, J.A.; Tschopp, J.; French, L.E. Activation of the IL-1beta-processing inflammasome is involved in contact hypersensitivity. J. Investig. Dermatol. 2007, 127, 1956-1963. [CrossRef]

16. León Machado, J.A.; Steimle, V. The MHC class II transactivator CIITA: Not (quite) the odd-one-out anymore among NLR proteins. Int. J. Mol. Sci. 2021, 22, 1074. [CrossRef] [PubMed]

17. Steimle, V.; Otten, L.A.; Zufferey, M.; Mach, B. Complementation cloning of an MHC class II transactivator mutated in hereditary MHC class II deficiency (or bare lymphocyte syndrome). Cell 1993, 75, 135-146. [CrossRef]

18. Chang, C.-H.; Guerder, S.; Hong, S.-C.; van Ewijk, W.; Flavell, R.A. Mice Lacking the MHC Class II Transactivator (CIITA) Show Tissue-Specific Impairment of MHC Class II Expression. Immunity 1996, 4, 167-178. [CrossRef]

19. Reith, W.; LeibundGut-Landmann, S.; Waldburger, J.-M. Regulation of MHC class II gene expression by the class II transactivator. Nat. Rev. Immunol. 2005, 5, 793-806. [CrossRef] [PubMed]

20. Choi, N.M.; Majumder, P.; Boss, J.M. Regulation of major histocompatibility complex class II genes. Curr. Opin. Immunol. 2011, 23, 81-87. [CrossRef] 
21. Albanesi Cavani, C.A.; Girolomoni, G. Interferon- $\gamma$-Stimulated Human Keratinocytes Express the Genes Necessary for the Production of Peptide-Loaded MHC Class II Molecules. J. Investig. Dermatol. 1998, 110, 138-142. [CrossRef]

22. Takagi, A.; Nishiyama, C.; Kanada, S.; Niwa, Y.; Fukuyama, K.; Ikeda, S.; Okumura, K.; Ogawa, H. Prolonged MHC class II expression and CIITA transcription in human keratinocytes. Biochem. Biophys. Res. Commun. 2006, 347, 388-393. [CrossRef]

23. Tamoutounour, S.; Han, S.-J.; Deckers, J.; Constantinides, M.G.; Hurabielle, C.; Harrison, O.J.; Bouladoux, N.; Linehan, J.L.; Link, V.M.; Vujkovic-Cvijin, I.; et al. Keratinocyte-intrinsic MHCII expression controls microbiota-induced Th1 cell responses. Proc. Natl. Acad. Sci. USA 2019, 116, 23643-23652. [CrossRef]

24. Czernielewski, J.M.; Bagot, M. Class II MHC antigen expression by human keratinocytes results from lympho-epidermal interactions and gamma-interferon production. Clin. Exp. Immunol. 1986, 66, 295-302.

25. Aubock, J.; Romani, N.; Grubauer, G.; Fritsch, P. HLA-DR expression on keratinocytes is a common feature of diseased skin. Br. J. Dermatol. 1986, 114, 465-472. [CrossRef] [PubMed]

26. Krueger, J.G.; Krane, J.F.; Carter, D.M.; Gottlieb, A.B. Role of Growth Factors, Cytokines, and Their Receptors in the Pathogenesis of Psoriasis. J. Investig. Dermatol. 1990, 94, s135-s140. [CrossRef] [PubMed]

27. Wittmann, M.; Purwar, R.; Hartmann, C.; Gutzmer, R.; Werfel, T. Human Keratinocytes Respond to Interleukin-18: Implication for the Course of Chronic Inflammatory Skin Diseases. J. Investig. Dermatol. 2005, 124, 1225-1233. [CrossRef] [PubMed]

28. Mutis, T.; Bueger, M.; Bakker, A.; Ottenhoff, T.H.M. HLA Class II+ Human Keratinocytes present Mycobacterium leprae Antigens to CD4+ Thl-Like Cells. Scand. J. Immunol. 1993, 37, 43-51. [CrossRef] [PubMed]

29. Nickoloff, B.J.; Basham, T.Y.; Merigan, T.C.; Torseth, J.W.; Morhenn, V.B. Human Keratinocyte-Lymphocyte Reactions In Vitro. J. Investig. Dermatol. 1986, 87, 11-18. [CrossRef]

30. Gaspari, A.A.; Katz, S.I. Induction and functional characterization of class II MHC (Ia) antigens on murine keratinocytes. J. Immunol. 1988, 140, 2956-2963.

31. Niederwieser, D.; Auböck, J.; Troppmair, J.; Herold, M.; Schuler, G.; Boeck, G.; Lotz, J.; Fritsch, P.; Huber, C. IFN-mediated induction of MHC antigen expression on human keratinocytes and its influence on in vitro alloimmune responses. J. Immunol. 1988, 140, 2556-2564. [PubMed]

32. Ortiz-Sanchez, E.; Chávez-Olmos, P.; Pina-Sanchez, P.; Salcedo, M.; Garrigo, E. Expression of the costimulatory molecule CD86, but not CD80, in keratinocytes of normal cervical epithelium and human papillomavirus-16 positive low squamous intraepithelial lesions. Int. J. Gynecol. Cancer 2007, 17, 571-580. [CrossRef]

33. Nickoloff, B.J.; Mitra, R.S.; Lee, K.; Turka, L.A.; Green, J.; Thompson, C.; Shimizu, Y. Discordant expression of CD28 ligands, BB-1, and B7 on keratinocytes in vitro and psoriatic cells in vivo. Am. J. Pathol. 1993, 142, 1029-1040.

34. Gaspari, A.A.; Ferbel, B.; Chen, Z.; Razvi, F.; Polakowska, R. Accessory and Alloantigen-Presenting Cell Functions of A431 Keratinocytes That Stably Express the B7 Antigen. Cell. Immunol. 1993, 149, 291-302. [CrossRef]

35. Nickoloff, B.J.; Turka, L.A. Immunological functions of non-professional antigen-presenting cells: New insights from studies of T-cell interactions with keratinocytes. Immunol. Today 1994, 15, 464-469. [CrossRef]

36. Kofoed, E.M.; Vance, R.E. Innate immune recognition of bacterial ligands by NAIPs determines inflammasome specificity. Nature 2011, 477, 592-595. [CrossRef]

37. Maier, J.K.X.; Lahoua, Z.; Gendron, N.H.; Fetni, R.; Johnston, A.; Davoodi, J.; Rasper, D.; Roy, S.; Slack, R.S.; Nicholson, D.W.; et al. The Neuronal Apoptosis Inhibitory Protein Is a Direct Inhibitor of Caspases 3 and 7. J. Neurosci. 2002, 22, 2035-2043. [CrossRef] [PubMed]

38. Davoodi, J.; Ghahremani, M.-H.; Es-haghi, A.; Mohammad-gholi, A.; MacKenzie, A. Neuronal apoptosis inhibitory protein, NAIP, is an inhibitor of procaspase-9. Int. J. Biochem. Cell Biol. 2010, 42, 958-964. [CrossRef]

39. Sanna, M.G.; da Correia, J.S.; Ducrey, O.; Lee, J.; Nomoto, K.; Schrantz, N.; Deveraux, Q.L.; Ulevitch, R.J. IAP Suppression of Apoptosis Involves Distinct Mechanisms: The TAK1/JNK1 Signaling Cascade and Caspase Inhibition. Mol. Cell. Biol. 2002, 22, 1754-1766. [CrossRef] [PubMed]

40. Vance, R.E. The NAIP/NLRC4 inflammasomes. Curr. Opin. Immunol. 2015, 32, 84-89. [CrossRef] [PubMed]

41. Yang, J.; Zhao, Y.; Shi, J.; Shao, F. Human NAIP and mouse NAIP1 recognize bacterial type III secretion needle protein for inflammasome activation. Proc. Natl. Acad. Sci. USA 2013, 110, 14408-14413. [CrossRef]

42. Mariathasan, S.; Newton, K.; Monack, D.M.; Vucic, D.; French, D.M.; Lee, W.P.; Roose-Girma, M.; Erickson, S.; Dixit, V.M. Differential activation of the inflammasome by caspase-1 adaptors ASC and Ipaf. Nature 2004, 430, 213-218. [CrossRef]

43. Zamboni, D.S.; Kobayashi, K.S.; Kohlsdorf, T.; Ogura, Y.; Long, E.M.; Vance, R.E.; Kuida, K.; Mariathasan, S.; Dixit, V.M.; Flavell, R.A.; et al. The Bircle cytosolic pattern-recognition receptor contributes to the detection and control of Legionella pneumophila infection. Nat. Immunol. 2006, 7, 318-325. [CrossRef]

44. Human Protein Atlas NAIP. Available online: https:/ / www.proteinatlas.org/ENSG00000249437-NAIP (accessed on 19 February 2021).

45. Velloso, F.J.; Trombetta-Lima, M.; Anschau, V.; Sogayar, M.C.; Correa, R.G. NOD-like receptors: Major players (and targets) in the interface between innate immunity and cancer. Biosci. Rep. 2019, 39. [CrossRef]

46. Human Protein Atlas. Available online: http://www.proteinatlas.org (accessed on 31 January 2021).

47. Correa, R.G.; Milutinovic, S.; Reed, J.C. Roles of NOD1 (NLRC1) and NOD2 (NLRC2) in innate immunity and inflammatory diseases. Biosci. Rep. 2012, 32, 597-608. [CrossRef] [PubMed] 
48. Travassos, L.H.; Carneiro, L.A.M.; Girardin, S.; Philpott, D.J. Nod proteins link bacterial sensing and autophagy. Autophagy 2010, 6, 409-411. [CrossRef]

49. Human Protein Atlas NOD1. Available online: https://www.proteinatlas.org/ENSG00000106100-NOD1/celltype (accessed on 19 February 2021).

50. Human Protein Atlas NOD2. Available online: https://www.proteinatlas.org/ENSG00000167207-NOD2/celltype (accessed on 19 February 2021).

51. Harder, J.; Núñez, G. Functional Expression of the Intracellular Pattern Recognition Receptor NOD1 in Human Keratinocytes. J. Investig. Dermatol. 2009, 129, 1299-1302. [CrossRef] [PubMed]

52. Voss, E.; Wehkamp, J.; Wehkamp, K.; Stange, E.F.; Schröder, J.M.; Harder, J. NOD2/CARD15 mediates induction of the antimicrobial peptide human beta-defensin-2. J. Biol. Chem. 2006, 281, 2005-2011. [CrossRef]

53. Weidinger, S.; Klopp, N.; Rummler, L.; Wagenpfeil, S.; Novak, N.; Baurecht, H.-J.; Groer, W.; Darsow, U.; Heinrich, J.; Gauger, A. Association of NOD1 polymorphisms with atopic eczema and related phenotypes. J. Allergy Clin. Immunol. 2005, 116, 177-184. [CrossRef] [PubMed]

54. Kabesch, M.; Peters, W.; Carr, D.; Leupold, W.; Weiland, S.K.; von Mutius, E. Association between polymorphisms in caspase recruitment domain containing protein 15 and allergy in two German populations. J. Allergy Clin. Immunol. 2003, 111, 813-817. [CrossRef]

55. Macaluso, F.; Nothnagel, M.; Parwez, Q.; Petrasch-Parwez, E.; Bechara, F.G.; Epplen, J.T.; Hoffjan, S. Polymorphisms in NACHTLRR (NLR) genes in atopic dermatitis. Exp. Dermatol. 2007, 16, 692-698. [CrossRef] [PubMed]

56. Bylund, S.; Von Kobyletzki, L.B.; Svalstedt, M.; Svensson, Å. Prevalence and incidence of atopic dermatitis: A systematic review. Acta Derm. Venereol. 2020, 100, 320-329. [CrossRef]

57. Tsang, M.S.M.; Hou, T.; Chan, B.C.L.; Wong, C.K. Immunological roles of NLR in allergic diseases and its underlying mechanisms. Int. J. Mol. Sci. 2021, 22, 1507. [CrossRef]

58. De Benedetto, A.; Kubo, A.; Beck, L.A. Skin Barrier Disruption: A Requirement for Allergen Sensitization? J. Investig. Dermatol. 2012, 132, 949-963. [CrossRef]

59. Deshmukh, H.S.; Hamburger, J.B.; Ahn, S.H.; McCafferty, D.G.; Yang, S.R.; Fowler, V.G. Critical Role of NOD2 in Regulating the Immune Response to Staphylococcus aureus. Infect. Immun. 2009, 77, 1376-1382. [CrossRef]

60. Hruz, P.; Zinkernagel, A.S.; Jenikova, G.; Botwin, G.J.; Hugot, J.-P.; Karin, M.; Nizet, V.; Eckmann, L. NOD2 contributes to cutaneous defense against Staphylococcus aureus through -toxin-dependent innate immune activation. Proc. Natl. Acad. Sci. USA 2009, 106, 12873-12878. [CrossRef] [PubMed]

61. Roth, S.A.; Simanski, M.; Rademacher, F.; Schröder, L.; Harder, J. The Pattern Recognition Receptor NOD2 Mediates Staphylococcus aureus -Induced IL-17C Expression in Keratinocytes. J. Investig. Dermatol. 2014, 134, 374-380. [CrossRef]

62. Rahman, P.; Bartlett, S.; Siannis, F.; Pellett, F.J.; Farewell, V.T.; Peddle, L.; Schentag, C.T.; Alderdice, C.A.; Hamilton, S.; Khraishi, M.; et al. CARD15: A Pleiotropic Autoimmune Gene That Confers Susceptibility to Psoriatic Arthritis. Am. J. Hum. Genet. 2003, 73, 677-681. [CrossRef]

63. Zhu, K.; Yin, X.; Tang, X.; Zhang, F.; Yang, S.; Zhang, X. Meta-analysis of NOD2/CARD15 polymorphisms with psoriasis and psoriatic arthritis. Rheumatol. Int. 2012, 32, 1893-1900. [CrossRef]

64. Christophers, E.; Metzler, G.; Röcken, M. Bimodal immune activation in psoriasis. Br. J. Dermatol. 2014, 170, 59-65. [CrossRef] [PubMed]

65. Rendon, A.; Schäkel, K. Psoriasis Pathogenesis and Treatment. Int. J. Mol. Sci. 2019, 20, 1475. [CrossRef] [PubMed]

66. Bozó, R.; Flink, L.B.; Belső, N.; Gubán, B.; Széll, M.; Kemény, L.; Bata-Csörgő, Z. Could basement membrane alterations, resembling micro-wounds at the dermo-epidermal junction in psoriatic non-lesional skin, make the skin susceptible to lesion formation? Exp. Dermatol. 2021, 1-8. [CrossRef]

67. Tervaniemi, M.; Katayama, S.; Skoog, T.; Siitonen, H.; Vuola, J.; Nuutila, K.; Sormunen, R.; Johnsson, A.; Linnarsson, S.; Suomela, S.; et al. NOD-like receptor signaling and inflammasome-related pathways are highlighted in psoriatic epidermis. Sci. Rep. 2016, 6, 22745. [CrossRef]

68. Hedl, M.; Li, J.; Cho, J.H.; Abraham, C. Chronic stimulation of Nod2 mediates tolerance to bacterial products. Proc. Natl. Acad. Sci. USA 2007, 104, 19440-19445. [CrossRef]

69. Guryanova, S.; Udzhukhu, V.; Kubylinsky, A. Pathogenetic Therapy of Psoriasis by Muramyl Peptide. Front. Immunol. 2019, 10. [CrossRef]

70. Human Protein Atlas NLRC5. Available online: https://www.proteinatlas.org/ENSG00000140853-NLRC5/celltype (accessed on 19 February 2021).

71. Mótyán, J.; Bagossi, P.; Benkő, S.; Tőzsér, J. A molecular model of the full-length human NOD-like receptor family CARD domain containing 5 (NLRC5) protein. BMC Bioinform. 2013, 14, 275. [CrossRef]

72. Downs, I.; Vijayan, S.; Sidiq, T.; Kobayashi, K.S. CITA/NLRC5: A critical transcriptional regulator of MHC class I gene expression. BioFactors 2016, 42, 349-357. [CrossRef] [PubMed]

73. Neerincx, A.; Castro, W.; Guarda, G.; Kufer, T.A. NLRC5, at the Heart of Antigen Presentation. Front. Immunol. 2013, 4. [CrossRef] [PubMed]

74. Kobayashi, K.S.; van den Elsen, P.J. NLRC5: A key regulator of MHC class I-dependent immune responses. Nat. Rev. Immunol. 2012, 12, 813-820. [CrossRef] [PubMed] 
75. Neerincx, A.; Jakobshagen, K.; Utermöhlen, O.; Büning, H.; Steimle, V.; Kufer, T.A. The N-Terminal Domain of NLRC5 Confers Transcriptional Activity for MHC Class I and II Gene Expression. J. Immunol. 2014, 193, 3090-3100. [CrossRef]

76. Benkő, S.; Kovács, E.G.; Hezel, F.; Kufer, T.A. NLRC5 Functions beyond MHC I Regulation—What Do We Know So Far? Front. Immunol. 2017, 8. [CrossRef]

77. Cui, J.; Zhu, L.; Xia, X.; Wang, H.Y.; Legras, X.; Hong, J.; Ji, J.; Shen, P.; Zheng, S.; Chen, Z.J.; et al. NLRC5 Negatively Regulates the NF- $\kappa B$ and Type I Interferon Signaling Pathways. Cell 2010, 141, 483-496. [CrossRef] [PubMed]

78. Benko, S.; Magalhaes, J.G.; Philpott, D.J.; Girardin, S.E. NLRC5 Limits the Activation of Inflammatory Pathways. J. Immunol. 2010, 185, 1681-1691. [CrossRef]

79. Kuenzel, S.; Till, A.; Winkler, M.; Häsler, R.; Lipinski, S.; Jung, S.; Grötzinger, J.; Fickenscher, H.; Schreiber, S.; Rosenstiel, P. The Nucleotide-Binding Oligomerization Domain-Like Receptor NLRC5 Is Involved in IFN-Dependent Antiviral Immune Responses. J. Immunol. 2010, 184, 1990-2000. [CrossRef]

80. Neerincx, A.; Lautz, K.; Menning, M.; Kremmer, E.; Zigrino, P.; Hösel, M.; Büning, H.; Schwarzenbacher, R.; Kufer, T.A. A Role for the Human Nucleotide-binding Domain, Leucine-rich Repeat-containing Family Member NLRC5 in Antiviral Responses*. J. Biol. Chem. 2010, 285, 26223-26232. [CrossRef] [PubMed]

81. Ranjan, P.; Singh, N.; Kumar, A.; Neerincx, A.; Kremmer, E.; Cao, W.; Davis, W.G.; Katz, J.M.; Gangappa, S.; Lin, R.; et al. NLRC5 interacts with RIG-I to induce a robust antiviral response against influenza virus infection. Eur. J. Immunol. 2015, 45, 758-772. [CrossRef]

82. Davis, B.K.; Roberts, R.A.; Huang, M.T.; Willingham, S.B.; Conti, B.J.; Brickey, W.J.; Barker, B.R.; Kwan, M.; Taxman, D.J.; Accavitti-Loper, M.-A.; et al. Cutting Edge: NLRC5-Dependent Activation of the Inflammasome. J. Immunol. 2011, 186, 1333-1337. [CrossRef]

83. Spoerri, I.; Herms, S.; Eytan, O.; Sair, O.; Heinimann, K.; Sprecher, E.; Itin, P.H.; Burger, B. Immune-regulatory genes as possible modifiers of familial pityriasis rubra pilaris_Lessons from a family with PRP and psoriasis. J. Eur. Acad. Dermatol. Venereol. 2018. [CrossRef]

84. Kim, H.; Kim, H.; Feng, Y.; Li, Y.; Tamiya, H.; Tocci, S.; Ronai, Z.A. PRMT5 control of cGAS/STING and NLRC5 pathways defines melanoma response to antitumor immunity. Sci. Transl. Med. 2020, 12, eaaz5683. [CrossRef]

85. Ma, H.-L.; Zhao, X.-F.; Chen, G.-Z.; Fang, R.-H.; Zhang, F.-R. Silencing NLRC5 inhibits extracellular matrix expression in keloid fibroblasts via inhibition of transforming growth factor- $\beta 1 /$ Smad signaling pathway. Biomed. Pharmacother. 2016, 83, 1016-1021. [CrossRef] [PubMed]

86. Corridoni, D.; Arseneau, K.O.; Cifone, M.G.; Cominelli, F. The Dual Role of Nod-Like Receptors in Mucosal Innate Immunity and Chronic Intestinal Inflammation. Front. Immunol. 2014, 5, 317. [CrossRef]

87. Sand, J.; Haertel, E.; Biedermann, T.; Contassot, E.; Reichmann, E.; French, L.E.; Werner, S.; Beer, H.-D. Expression of inflammasome proteins and inflammasome activation occurs in human, but not in murine keratinocytes. Cell Death Dis. 2018, 9, 24. [CrossRef]

88. Niebuhr, M.; Baumert, K.; Heratizadeh, A.; Satzger, I.; Werfel, T. Impaired NLRP3 inflammasome expression and function in atopic dermatitis due to Th2 milieu. Allergy 2014. [CrossRef]

89. Schroder, K.; Tschopp, J. The inflammasomes. Cell 2010, 140, 821-832. [CrossRef] [PubMed]

90. Feldmeyer, L.; Keller, M.; Niklaus, G.; Hohl, D.; Werner, S.; Beer, H.-D. The inflammasome mediates UVB-induced activation and secretion of interleukin-1beta by keratinocytes. Curr. Biol. 2007, 17, 1140-1145. [CrossRef]

91. Thürmann, L.; Grützmann, K.; Klös, M.; Bieg, M.; Winter, M.; Polte, T.; Bauer, T.; Schick, M.; Bewerunge-Hudler, M.; Röder, S.; et al. Early-onset childhood atopic dermatitis is related to NLRP2 repression. J. Allergy Clin. Immunol. 2018, 141, 1482-1485.e16. [CrossRef] [PubMed]

92. Levandowski, C.B.; Mailloux, C.M.; Ferrara, T.M.; Gowan, K.; Ben, S.; Jin, Y.; McFann, K.K.; Holland, P.J.; Fain, P.R.; Dinarello, C.A.; et al. NLRP1 haplotypes associated with vitiligo and autoimmunity increase interleukin-1 processing via the NLRP1 inflammasome. Proc. Natl. Acad. Sci. USA 2013, 110, 2952-2956. [CrossRef]

93. Bivik, C.; Verma, D.; Winge, M.C.; Lieden, A.; Bradley, M.; Rosdahl, I.; Söderkvist, P. Genetic Variation in the Inflammasome and Atopic Dermatitis Susceptibility. J. Investig. Dermatol. 2013, 133, 2486-2489. [CrossRef]

94. Ekman, A.-K.; Verma, D.; Fredrikson, M.; Bivik, C.; Enerbäck, C. Genetic variations of NLRP1: Susceptibility in psoriasis. Br. J. Dermatol. 2014, 171, 1517-1520. [CrossRef] [PubMed]

95. Hirota, T.; Takahashi, A.; Kubo, M.; Tsunoda, T.; Tomita, K.; Sakashita, M.; Yamada, T.; Fujieda, S.; Tanaka, S.; Doi, S.; et al. Genome-wide association study identifies eight new susceptibility loci for atopic dermatitis in the Japanese population. Nat. Genet. 2012, 44, 1222-1226. [CrossRef]

96. Zhong, F.L.; Mamaï, O.; Sborgi, L.; Boussofara, L.; Hopkins, R.; Robinson, K.; Szeverényi, I.; Takeichi, T.; Balaji, R.; Lau, A.; et al. Germline NLRP1 Mutations Cause Skin Inflammatory and Cancer Susceptibility Syndromes via Inflammasome Activation. Cell 2016, 167, 187-202.e17. [CrossRef]

97. Martinon, F.; Burns, K.; Tschopp, J. The Inflammasome. Mol. Cell 2002, 10, 417-426. [CrossRef]

98. Zhong, Y.; Kinio, A.; Saleh, M. Functions of NOD-Like Receptors in Human Diseases. Front. Immunol. 2013, 4, 1-18. [CrossRef]

99. Faustin, B.; Lartigue, L.; Bruey, J.-M.; Luciano, F.; Sergienko, E.; Bailly-Maitre, B.; Volkmann, N.; Hanein, D.; Rouiller, I.; Reed, J.C. Reconstituted NALP1 Inflammasome Reveals Two-Step Mechanism of Caspase-1 Activation. Mol. Cell 2007, 25, 713-724. [CrossRef] 
100. Boyden, E.D.; Dietrich, W.F. Nalp1b controls mouse macrophage susceptibility to anthrax lethal toxin. Nat. Genet. 2006, 38, 240-244. [CrossRef]

101. Mitchell, P.S.; Sandstrom, A.; Vance, R.E. The NLRP1 inflammasome: New mechanistic insights and unresolved mysteries. Curr. Opin. Immunol. 2019, 60, 37-45. [CrossRef] [PubMed]

102. Sandstrom, A.; Mitchell, P.S.; Goers, L.; Mu, E.W.; Lesser, C.F.; Vance, R.E. Functional degradation: A mechanism of NLRP1 inflammasome activation by diverse pathogen enzymes. Science 2019, 364, eaau1330. [CrossRef] [PubMed]

103. Chavarría-Smith, J.; Vance, R.E. Direct Proteolytic Cleavage of NLRP1B Is Necessary and Sufficient for Inflammasome Activation by Anthrax Lethal Factor. PLoS Pathog. 2013, 9, e1003452. [CrossRef]

104. Hellmich, K.A.; Levinsohn, J.L.; Fattah, R.; Newman, Z.L.; Maier, N.; Sastalla, I.; Liu, S.; Leppla, S.H.; Moayeri, M. Anthrax Lethal Factor Cleaves Mouse Nlrp1b in Both Toxin-Sensitive and Toxin-Resistant Macrophages. PLoS ONE 2012, 7, e49741. [CrossRef] [PubMed]

105. Levinsohn, J.L.; Newman, Z.L.; Hellmich, K.A.; Fattah, R.; Getz, M.A.; Liu, S.; Sastalla, I.; Leppla, S.H.; Moayeri, M. Anthrax Lethal Factor Cleavage of Nlrp1 Is Required for Activation of the Inflammasome. PLoS Pathog. 2012, 8, e1002638. [CrossRef] [PubMed]

106. Ewald, S.E.; Chavarria-Smith, J.; Boothroyd, J.C. NLRP1 Is an Inflammasome Sensor for Toxoplasma gondii. Infect. Immun. 2014, 82, 460-468. [CrossRef]

107. Bauernfried, S.; Scherr, M.J.; Pichlmair, A.; Duderstadt, K.E.; Hornung, V. Human NLRP1 is a sensor for double-stranded RNA. Science 2021, 371, eabd0811. [CrossRef] [PubMed]

108. Fenini, G.; Karakaya, T.; Hennig, P.; Di Filippo, M.; Beer, H.D. The NLRP1 inflammasome in human skin and beyond. Int. J. Mol. Sci. 2020, 21, 4788. [CrossRef]

109. Bachovchin, D.A. NLRP1: A jack of all trades, or a master of one? Mol. Cell 2021, 81, 423-425. [CrossRef]

110. Cavailles, P.; Flori, P.; Papapietro, O.; Bisanz, C.; Lagrange, D.; Pilloux, L.; Massera, C.; Cristinelli, S.; Jublot, D.; Bastien, O.; et al. A Highly Conserved Toxo1 Haplotype Directs Resistance to Toxoplasmosis and Its Associated Caspase-1 Dependent Killing of Parasite and Host Macrophage. PLoS Pathog. 2014, 10, e1004005. [CrossRef] [PubMed]

111. Jin, Y.; Mailloux, C.M.; Gowan, K.; Riccardi, S.L.; LaBerge, G.; Bennett, D.C.; Fain, P.R.; Spritz, R.A. NALP1 in Vitiligo-Associated Multiple Autoimmune Disease. N. Engl. J. Med. 2007, 356, 1216-1225. [CrossRef] [PubMed]

112. Boniface, K.; Jacquemin, C.; Darrigade, A.-S.; Dessarthe, B.; Martins, C.; Boukhedouni, N.; Vernisse, C.; Grasseau, A.; Thiolat, D.; Rambert, J.; et al. Vitiligo Skin Is Imprinted with Resident Memory CD8 T Cells Expressing CXCR3. J. Investig. Dermatol. 2018, 138, 355-364. [CrossRef]

113. Ciążyńska, M.; Bednarski, I.A.; Wódz, K.; Narbutt, J.; Lesiak, A. NLRP1 and NLRP3 inflammasomes as a new approach to skin carcinogenesis (Review). Oncol. Lett. 2020, 19, 1649-1656. [CrossRef]

114. Grigoryev, D.N.; Howell, M.D.; Watkins, T.N.; Chen, Y.-C.; Cheadle, C.; Boguniewicz, M.; Barnes, K.C.; Leung, D.Y.M. Vaccinia virus-specific molecular signature in atopic dermatitis skin. J. Allergy Clin. Immunol. 2010, 125, 153-159.e28. [CrossRef] [PubMed]

115. Bruey, J.M.; Bruey-Sedano, N.; Newman, R.; Chandler, S.; Stehlik, C.; Reed, J.C. PAN1/NALP2/PYPAF2, an Inducible Inflammatory Mediator That Regulates NF-KB and Caspase-1 Activation in Macrophages. J. Biol. Chem. 2004, 279, 51897-51907. [CrossRef]

116. Ji, S.; Shin, J.E.; Kim, Y.S.; Oh, J.-E.; Min, B.-M.; Choi, Y. Toll-Like Receptor 2 and NALP2 Mediate Induction of Human Beta-Defensins by Fusobacterium nucleatum in Gingival Epithelial Cells. Infect. Immun. 2009, 77, 1044-1052. [CrossRef]

117. Yoshikawa, Y.; Sasahara, Y.; Takeuchi, K.; Tsujimoto, Y.; Hashida-Okado, T.; Kitano, Y.; Hashimoto-Tamaoki, T. Transcriptional Analysis of Hair Follicle-Derived Keratinocytes from Donors with Atopic Dermatitis Reveals Enhanced Induction of IL32 Gene by IFN- $\gamma$. Int. J. Mol. Sci. 2013, 14, 3215-3227. [CrossRef]

118. Netea, M.G.; Nold-Petry, C.A.; Nold, M.F.; Joosten, L.A.B.; Opitz, B.; van der Meer, J.H.M.; van de Veerdonk, F.L.; Ferwerda, G.; Heinhuis, B.; Devesa, I.; et al. a Differential requirement for the activation of the inflammasome for processing and release of IL-1beta in monocytes and macrophages. Blood 2009, 113, 2324-2335. [CrossRef]

119. Pétrilli, V.; Papin, S.; Dostert, C.; Mayor, A.; Martinon, F.; Tschopp, J. Activation of the NALP3 inflammasome is triggered by low intracellular potassium concentration. Cell Death Differ. 2007, 14, 1583-1589. [CrossRef] [PubMed]

120. Martinon, F.; Pétrilli, V.; Mayor, A.; Tardivel, A.; Tschopp, J. Gout-associated uric acid crystals activate the NALP3 inflammasome. Nature 2006, 440, 237-241. [CrossRef]

121. Martinon, F.; Agostini, L.; Meylan, E.; Tschopp, J. Identification of Bacterial Muramyl Dipeptide as Activator of the NALP3/Cryopyrin Inflammasome. Curr. Biol. 2004, 14, 1929-1934. [CrossRef]

122. Kanneganti, T.-D.; Body-Malapel, M.; Amer, A.; Park, J.-H.; Whitfield, J.; Franchi, L.; Taraporewala, Z.F.; Miller, D.; Patton, J.T.; Inohara, N.; et al. Critical Role for Cryopyrin/Nalp3 in Activation of Caspase-1 in Response to Viral Infection and Doublestranded RNA. J. Biol. Chem. 2006, 281, 36560-36568. [CrossRef]

123. Broz, P.; Dixit, V.M. Inflammasomes: Mechanism of assembly, regulation and signalling. Nat. Rev. Immunol. 2016, 16, 407-420. [CrossRef]

124. He, W.; Wan, H.; Hu, L.; Chen, P.; Wang, X.; Huang, Z.; Yang, Z.-H.; Zhong, C.-Q.; Han, J. Gasdermin D is an executor of pyroptosis and required for interleukin-1 $\beta$ secretion. Cell Res. 2015, 25, 1285-1298. [CrossRef] [PubMed]

125. Rühl, S.; Broz, P. Caspase-11 activates a canonical NLRP3 inflammasome by promoting K + efflux. Eur. J. Immunol. 2015, 45, 2927-2936. [CrossRef] 
126. Shi, J.; Zhao, Y.; Wang, K.; Shi, X.; Wang, Y.; Huang, H.; Zhuang, Y.; Cai, T.; Wang, F.; Shao, F. Cleavage of GSDMD by inflammatory caspases determines pyroptotic cell death. Nature 2015, 526, 660-665. [CrossRef] [PubMed]

127. Grossi, S.; Fenini, G.; Kockmann, T.; Hennig, P.; Di Filippo, M.; Beer, H.-D. Inactivation of the Cytoprotective Major Vault Protein by Caspase-1 and -9 in Epithelial Cells during Apoptosis. J. Investig. Dermatol. 2020, 140, 1335-1345.e10. [CrossRef] [PubMed]

128. Zhuang, T.; Li, S.; Yi, X.; Guo, S.; Wang, Y.; Chen, J.; Liu, L.; Jian, Z.; Gao, T.; Kang, P.; et al. Tranilast Directly Targets NLRP3 to Protect Melanocytes from Keratinocyte-Derived IL-1 $\beta$ Under Oxidative Stress. Front. Cell Dev. Biol. 2020, 8, 588. [CrossRef]

129. Dai, X.; Tohyama, M.; Murakami, M.; Sayama, K. Epidermal keratinocytes sense dsRNA via the NLRP3 inflammasome, mediating interleukin (IL)-1 $\beta$ and IL-18 release. Exp. Dermatol. 2017, 26, 904-911. [CrossRef] [PubMed]

130. Zhang, C.; Xiao, C.; Dang, E.; Cao, J.; Zhu, Z.; Fu, M.; Yao, X.; Liu, Y.; Jin, B.; Wang, G.; et al. CD100-Plexin-B2 Promotes the Inflammation in Psoriasis by Activating NF-kB and the Inflammasome in Keratinocytes. J. Investig. Dermatol. 2018, 138, 375-383. [CrossRef] [PubMed]

131. Hasegawa, T.; Nakashima, M.; Suzuki, Y. Nuclear DNA damage-triggered NLRP3 inflammasome activation promotes UVBinduced inflammatory responses in human keratinocytes. Biochem. Biophys. Res. Commun. 2016, 477, 329-335. [CrossRef]

132. Ito, H.; Kanbe, A.; Sakai, H.; Seishima, M. Activation of NLRP3 signalling accelerates skin wound healing. Exp. Dermatol. 2018, 27, 80-86. [CrossRef]

133. Weinheimer-Haus, E.M.; Mirza, R.E.; Koh, T.J. Nod-Like Receptor Protein-3 Inflammasome Plays an Important Role during Early Stages of Wound Healing. PLoS ONE 2015, 10, e0119106. [CrossRef]

134. Wang, T.; Zhao, J.; Zhang, J.; Mei, J.; Shao, M.; Pan, Y.; Yang, W.; Jiang, Y.; Liu, F.; Jia, W. Heparan sulfate inhibits inflammation and improves wound healing by downregulating the NLR family pyrin domain containing 3 (NLRP3) inflammasome in diabetic rats. J. Diabetes 2018, 10, 556-563. [CrossRef] [PubMed]

135. Qing, L.; Fu, J.; Wu, P.; Zhou, Z.; Yu, F.; Tang, J. Metformin induces the $\mathrm{m} 2$ macrophage polarization to accelerate the wound healing via regulating ampk/mtor/nlrp3 inflammasome singling pathway. Am. J. Transl. Res. 2019, 11, 655-668.

136. Wang, D.; Duncan, B.; Li, X.; Shi, J. The role of NLRP3 inflammasome in infection-related, immune-mediated and autoimmune skin diseases. J. Dermatol. Sci. 2020, 98, 146-151. [CrossRef]

137. Li, S.; Kang, P.; Zhang, W.; Jian, Z.; Zhang, Q.; Yi, X.; Guo, S.; Guo, W.; Shi, Q.; Li, B.; et al. Activated NLR family pyrin domain containing 3 (NLRP3) inflammasome in keratinocytes promotes cutaneous T-cell response in patients with vitiligo. J. Allergy Clin. Immunol. 2020, 145, 632-645. [CrossRef] [PubMed]

138. Li, Z.J.; Choi, D.K.; Sohn, K.C.; Seo, M.S.; Lee, H.E.; Lee, Y.; Seo, Y.J.; Lee, Y.H.; Shi, G.; Zouboulis, C.C.; et al. Propionibacterium acnes Activates the NLRP3 Inflammasome in Human Sebocytes. J. Investig. Dermatol. 2014, 134, 2747-2756. [CrossRef]

139. Szabó, K.; Erdei, L.; Bolla, B.S.; Tax, G.; Bíró, T.; Kemény, L. Factors shaping the composition of the cutaneous microbiota. Br. J. Dermatol. 2017, 176, 344-351. [CrossRef] [PubMed]

140. McLaughlin, J.; Watterson, S.; Layton, A.M.; Bjourson, A.J.; Barnard, E.; McDowell, A. Propionibacterium acnes and Acne Vulgaris: New Insights from the Integration of Population Genetic, Multi-Omic, Biochemical and Host-Microbe Studies. Microorganisms 2019, 7, 128. [CrossRef]

141. Shen, C.; Wang, Q.Z.; Shen, Z.Y.; Yuan, H.Y.; Yu, W.J.; Chen, X.D.; Xu, H. Genetic association between the NLRP3 gene and acne vulgaris in a Chinese population. Clin. Exp. Dermatol. 2019, 44, 184-189. [CrossRef]

142. Muñoz-Planillo, R.; Franchi, L.; Miller, L.S.; Núñez, G. A Critical Role for Hemolysins and Bacterial Lipoproteins in Staphylococcus aureus-Induced Activation of the Nlrp3 Inflammasome. J. Immunol. 2009, 183, 3942-3948. [CrossRef] [PubMed]

143. Craven, R.R.; Gao, X.; Allen, I.C.; Gris, D.; Wardenburg, J.B.; McElvania-TeKippe, E.; Ting, J.P.; Duncan, J.A. Staphylococcus aureus $\alpha$-Hemolysin Activates the NLRP3-Inflammasome in Human and Mouse Monocytic Cells. PLoS ONE 2009, 4, e7446. [CrossRef]

144. Dai, X.; Sayama, K.; Tohyama, M.; Shirakata, Y.; Hanakawa, Y.; Tokumaru, S.; Yang, L.; Hirakawa, S.; Hashimoto, K. Mite allergen is a danger signal for the skin via activation of inflammasome in keratinocytes. J. Allergy Clin. Immunol. 2011, 127, 806-814.e4. [CrossRef]

145. Su, F.; Xia, Y.; Huang, M.; Zhang, L.; Chen, L. Expression of NLPR3 in Psoriasis Is Associated with Enhancement of Interleukin-1 $\beta$ and Caspase-1. Med. Sci. Monit. 2018, 24, 7909-7913. [CrossRef] [PubMed]

146. Irrera, N.; Vaccaro, M.; Bitto, A.; Pallio, G.; Pizzino, G.; Lentini, M.; Arcoraci, V.; Minutoli, L.; Scuruchi, M.; Cutroneo, G.; et al. BAY 11-7082 inhibits the NF-KB and NLRP3 inflammasome pathways and protects against IMQ-induced psoriasis. Clin. Sci. 2017, 131, 487-498. [CrossRef] [PubMed]

147. Yu, P.; Hao, S.; Zheng, H.; Zhao, X.; Li, Y. Association of NLRP1 and NLRP3 Polymorphisms with Psoriasis Vulgaris Risk in the Chinese Han Population. Biomed. Res. Int. 2018, 2018, 1-8. [CrossRef]

148. Primiano, M.J.; Lefker, B.A.; Bowman, M.R.; Bree, A.G.; Hubeau, C.; Bonin, P.D.; Mangan, M.; Dower, K.; Monks, B.G.; Cushing, L.; et al. Efficacy and Pharmacology of the NLRP3 Inflammasome Inhibitor CP-456,773 (CRID3) in Murine Models of Dermal and Pulmonary Inflammation. J. Immunol. 2016, 197, 2421-2433. [CrossRef]

149. Deng, G.; Chen, W.; Wang, P.; Zhan, T.; Zheng, W.; Gu, Z.; Wang, X.; Ji, X.; Sun, Y. Inhibition of NLRP3 inflammasome-mediated pyroptosis in macrophage by cycloastragenol contributes to amelioration of imiquimod-induced psoriasis-like skin inflammation in mice. Int. Immunopharmacol. 2019, 74, 105682. [CrossRef]

150. Edqvist, P.D.; Fagerberg, L.; Hallström, B.M.; Danielsson, A.; Edlund, K.; Uhlén, M.; Pontén, F. Expression of Human Skin-Specific Genes Defined by Transcriptomics and Antibody-Based Profiling. J. Histochem. Cytochem. 2015, 63. [CrossRef] 
151. Tanaka, S.; Mizushina, Y.; Kato, Y.; Tamura, M.; Shiroishi, T. Functional Conservation of Gsdma Cluster Genes Speci fi cally Duplicated in the Mouse Genome. G3 Genes Genomes Genet. 2013, 3, 1843-1850. [CrossRef]

152. Lautz, K.; Damm, A.; Menning, M.; Wenger, J.; Adam, A.C.; Zigrino, P.; Kremmer, E.; Kufer, T.A. NLRP10 enhances shigellainduced pro-inflammatory responses. Cell. Microbiol. 2012, 14, 1568-1583. [CrossRef] [PubMed]

153. Imamura, R.; Wang, Y.; Kinoshita, T.; Suzuki, M.; Noda, T.; Sagara, J.; Taniguchi, S.; Okamoto, H.; Suda, T. Anti-Inflammatory Activity of PYNOD and Its Mechanism in Humans and Mice. J. Immunol. 2010, 184, 5874-5884. [CrossRef]

154. Wang, Y.; Hasegawa, M.; Imamura, R.; Kinoshita, T.; Kondo, C.; Konaka, K.; Suda, T. PYNOD, a novel Apaf-1/CED4-like protein is an inhibitor of ASC and caspase-1. Int. Immunol. 2004, 16, 777-786. [CrossRef] [PubMed]

155. Joly, S.; Eisenbarth, S.C.; Olivier, A.K.; Williams, A.; Kaplan, D.H.; Cassel, S.L.; Flavell, R.A.; Sutterwala, F.S. Cutting Edge: Nlrp10 Is Essential for Protective Antifungal Adaptive Immunity against Candida albicans. J. Immunol. 2012, 189, 4713-4717. [CrossRef]

156. Eisenbarth, S.C.; Williams, A.; Colegio, O.R.; Meng, H.; Strowig, T.; Rongvaux, A.; Henao-Mejia, J.; Thaiss, C.A.; Joly, S.; Gonzalez, D.G.; et al. NLRP10 is a NOD-like receptor essential to initiate adaptive immunity by dendritic cells. Nature 2012, 484, 510-513. [CrossRef]

157. Damm, A.; Giebeler, N.; Zamek, J.; Zigrino, P.; Kufer, T.A. Epidermal NLRP10 contributes to contact hypersensitivity responses in mice. Eur. J. Immunol. 2016, 46, 1959-1969. [CrossRef] [PubMed]

158. Suárez-Fariñas, M.; Tintle, S.J.; Shemer, A.; Chiricozzi, A.; Nograles, K.; Cardinale, I.; Duan, S.; Bowcock, A.M.; Krueger, J.G.; Guttman-Yassky, E. Nonlesional atopic dermatitis skin is characterized by broad terminal differentiation defects and variable immune abnormalities. J. Allergy Clin. Immunol. 2011, 127, 954-964.e4. [CrossRef]

159. Reubold, T.F.; Hahne, G.; Wohlgemuth, S.; Eschenburg, S. Crystal structure of the leucine-rich repeat domain of the NOD-like receptor NLRP1: Implications for binding of muramyl dipeptide. FEBS Lett. 2014, 588, 3327-3332. [CrossRef] [PubMed]

160. Arnoult, D.; Soares, F.; Tattoli, I.; Castanier, C.; Philpott, D.J.; Girardin, S.E. An N-terminal addressing sequence targets NLRX1 to the mitochondrial matrix. J. Cell Sci. 2009, 122, 3161-3168. [CrossRef]

161. Moore, C.B.; Bergstralh, D.T.; Duncan, J.A.; Lei, Y.; Morrison, T.E.; Zimmermann, A.G.; Accavitti-Loper, M.A.; Madden, V.J.; Sun, L.; Ye, Z.; et al. NLRX1 is a regulator of mitochondrial antiviral immunity. Nature 2008, 451, 573-577. [CrossRef]

162. Tattoli, I.; Carneiro, L.A.; Jéhanno, M.; Magalhaes, J.G.; Shu, Y.; Philpott, D.J.; Arnoult, D.; Girardin, S.E. NLRX1 is a mitochondrial NOD-like receptor that amplifies NF-KB and JNK pathways by inducing reactive oxygen species production. EMBO Rep. 2008, 9, 293-300. [CrossRef]

163. Hung, S.-C.; Huang, P.-R.; Almeida-da-Silva, C.L.C.; Atanasova, K.R.; Yilmaz, O.; Ojcius, D.M. NLRX1 modulates differentially NLRP3 inflammasome activation and NF-kB signaling during Fusobacterium nucleatum infection. Microbes Infect. 2018, 20, 615-625. [CrossRef]

164. Fekete, T.; Bencze, D.; Bíró, E.; Benkő, S.; Pázmándi, K. Focusing on the Cell Type Specific Regulatory Actions of NLRX1. Int. J. Mol. Sci. 2021, 22, 1316. [CrossRef]

165. Mestas, J.; Hughes, C.C.W. Of Mice and Not Men: Differences between Mouse and Human Immunology. J. Immunol. 2004, 172, 2731-2738. [CrossRef]

166. Zomer, H.D.; Trentin, A.G. Skin wound healing in humans and mice: Challenges in translational research. J. Dermatol. Sci. 2018, 90, 3-12. [CrossRef] [PubMed]

167. Vaure, C.; Liu, Y. A Comparative Review of Toll-Like Receptor 4 Expression and Functionality in Different Animal Species. Front. Immunol. 2014, 5, 316. [CrossRef]

168. Chen, L.; Guo, S.; Ranzer, M.J.; DiPietro, L.A. Toll-Like Receptor 4 Has an Essential Role in Early Skin Wound Healing. J. Investig. Dermatol. 2013, 133, 258-267. [CrossRef] [PubMed]

169. Iram, N.; Mildner, M.; Prior, M.; Petzelbauer, P.; Fiala, C.; Hacker, S.; Schoppl, A.; Tschachler, E.; Elbe-Burger, A. Age-related changes in expression and function of Toll-like receptors in human skin. Development 2012, 139, 4210-4219. [CrossRef]

170. Applequist, S.E.; Wallin, R.P.A.; Ljunggren, H. Variable expression of Toll-like receptor in murine innate and adaptive immune cell lines. Int. Immunol. 2002, 14, 1065-1074. [CrossRef]

171. Drexler, S.K.; Bonsignore, L.; Masin, M.; Tardivel, A.; Jackstadt, R.; Hermeking, H.; Schneider, P.; Gross, O.; Tschopp, J.; Yazdi, A.S. Tissue-specific opposing functions of the inflammasome adaptor ASC in the regulation of epithelial skin carcinogenesis. Proc. Natl. Acad. Sci. USA 2012, 109, 18384-18389. [CrossRef] [PubMed]

172. Göblös, A.; Danis, J.; Vas, K.; Bata-Csörgő, Z.; Kemény, L.; Széll, M. Keratinocytes express functional CARD18, a negative regulator of inflammasome activation, and its altered expression in psoriasis may contribute to disease pathogenesis. Mol. Immunol. 2016, 73, 10-18. [CrossRef] [PubMed]

173. Qin, H.; Jin, J.; Fischer, H.; Mildner, M.; Gschwandtner, M.; Mlitz, V.; Eckhart, L.; Tschachler, E. The caspase-1 inhibitor CARD18 is specifically expressed during late differentiation of keratinocytes and its expression is lost in lichen planus. J. Dermatol. Sci. 2017, 87, 176-182. [CrossRef] 